\title{
Enhancement of Small-Scale Runoff Harvesting Ponds in East Africa
}

\author{
Teshome Lemma Yami* \\ The University of Oklahoma, 120 David L. Boren Blvd, Norman, Oklahoma, 73072 \\ *E-mail of the Corresponding author: Teshome.1.yami-1@ou.edu \\ Jim Francis Chamberlain \\ The University of Oklahoma, 202 W. Boyd St., Room 334, Norman, Oklahoma, 73072
}

\begin{abstract}
Ethiopia is one of the sub-Saharan African countries that is suffering from a recurring drought due to erratic rainfall occurrence both in amount and distribution. The livelihood of the largest portion of the people is dependent on rain-fed agriculture. Thus, crop failure is widely encountered by the peasants of the region because of the erratic nature of the rain and recurrent drought. As a result, millions of people depend upon relief assistance every year. It is therefore, necessary to detach the agricultural sector from its dependency on this seasonally fluctuating rainfall occurrence to supplement crop failure and feed the ever-increasing population of the country. This calls for harnessing runoff that occurs during wet seasons using water harvesting facilities and later use it in safeguarding crop failure through supplementary irrigation. Although harnessing runoff is not uncommon in Ethiopia, one of the major problems in this effort is the problem of excessive seepage losses and bank stability. This research work evaluates the methods that reduce seepage losses from ponds using locally available treatment materials. The treatment materials used were compacting the pond, lining the pond with termite mound and soil-straw mixture. These treatment methods resulted in reducing seepage losses and protected slope failure. soil-straw mixed and termite mound lined ponds contained water up to 47 and 43 days, respectively. This contrasts with the untreated (control) pond which contained water only for about 5 days. These methods are low-cost as local materials are used in the treatment and can be used in areas where seepage and bank stabilities are a problem. Moreover, this work is expected to pave the way for further research in the area.
\end{abstract}

Keywords: level-drop, pond, termite mound, treatment methods, water tightness

DOI: $10.7176 / \mathrm{JNSR} / 9-16-01$

Publication date: August $31^{\text {st }} 2019$

\section{Introduction}

\subsection{General}

Ethiopia has 12 river basins with a total annual runoff volume of 122 billion $\mathrm{m}^{3}$ of water and an estimated 2.6 6.5 billion $\mathrm{m}^{3}$ of ground water potential (Awulachew 2007). The potential irrigable land in Ethiopia is estimated at 3.7 million hectares (MoWR 2001). The total area currently under irrigation is estimated at 626,116 ha or about $17 \%$ of the total potential (Hagos et al. 2009). Most of the cultivated land in Ethiopia is under rainfed agriculture, but arid and semi-arid areas receive less than $500 \mathrm{~mm}$ to about $750 \mathrm{~mm}$ of rain per year (Hordofa et al. 2008). Ethiopia receives little annual rainfall along its northern and eastern coastal regions. The central and western part of the country have high rainfalls of up to $2000 \mathrm{~mm}$ annually and low lands have great variability in rainfall yearly linked to fluctuations in food availability and droughts (Stokes et al. 2010). Agriculture is the main economic activity of the country. However, due to lack of water storage capacity and large spatial and temporal variations in rainfall, there is not enough water for most farmers to produce more than one crop per year (Awulachew et al. 2005). Hence there are frequent crop failures owing to dry spells and droughts which have resulted in a chronic food shortage in the country.

According to OCHA (2006) (Figure S.1), the Oromia state annual rainfall of 500-1000 mm in central and eastern parts of the region and $1500-2000 \mathrm{~mm}$ in the western highlands. Oromia region is one of nine regional states in Ethiopia and the central and eastern part of the region is typical of many semi-arid, savannah regions that suffer from recurring droughts due to erratic rainfall. As a result, crop failure is widely encountered, exposing the peasants of the region to food insecurity and forced dependence upon relief assistance following every shortfall of rain. Moreover, climate change predictions suggest that water shortages may increase over longer time spans. Regarding the irrigation development in Oromia region, only $12 \%$ of 1.7 million hectares of suitable land has been utilized for surface irrigated agriculture (JICA 2013). FEWS NET (2011) reported that 4.5 million people required emergency humanitarian assistance in a year due to insufficient rainfall and extremely high food prices. To date, the efforts made to trap and store these water resources have seen limited success due to various technical and social problems. The attempts made so far have focused on small-scale water harvesting facilities such as the construction of micro earth dams. This dam is designed as a barrier constructed across a river or stream to create an impoundment of up to 15-meter height from the lowest ground level with a storage 
capacity less than 2 million cubic meters. Other water harvesting structures include river diversion, pumping works on perennial rivers, drip irrigation and hand dug-wells (Awulachew, 2005). The implementation of these schemes requires high capital expenditures (capital intensive), trained personnel, and longer construction periods. As a result, it is not feasible to develop these types of facilities to all farms and to extend the service to all parts of the region.

Water harvesting techniques are distinguished commonly by the source of water harvested as floodwater harvesting, groundwater harvesting and runoff harvesting. The term runoff (or rainwater) harvesting comprises the collection and storage of largely unconfined locally generated runoff from modified catchments (Prinz 1994). Currently there is an increasing practice to implement small water harvesting facilities (such as ponds) in areas that are susceptible to seasonal variability of rainfall. The ponds so constructed are therefore expected to solve the problem of crop failure through supplementary irrigation and help in the effort being made in the attainment of food security at the household level. Supplementary irrigation is a system where a strategic application of water is made at key stages in the crop growth period. However, most constructed water harvesting systems have high seepage losses and poor slope stability that the harnessed water is wasted without being used for the intended purposes. Thus, methods to increase the water tightness of ponds and reduce slope failure at low-cost are of high importance. In this study, four methods of lining ponds; compaction, termite mound, soil-straw mix and a control were constructed and evaluated for study in the Kemo-garbi area, Oromia region, Ethiopia. The purpose of the study was to find the most effective lining material(s) for sealing ponds and increasing slope stability.

\subsection{History of Water Harvesting (Catchment) Ponds}

Water harvesting ponds have been constructed all over the world to harness runoff water for subsequent uses such as watering cattle, human drinking water, and supplementary irrigation for crops and horticultural purposes. Water harvesting methods were a vital part of the water supply system of many ancient settlements in the dry lands of the Mediterranean region and Western Asia (Beckers et al. 2013). Rainwater harvesting, and management has been practiced in Mewar Region, India, since over 4500 years ago (Narpat 2011). Ancient civilizations in many countries like Jordan, Mesopotamia, Yemen, Pakistan, India, and China in Asia continent and Tunisia, Somalia, Sudan, and Burkina Faso in Africa have utilized different techniques of water harvesting for crop production purposes (Beckers et al. 2013). Examples of other ancient water harvesting systems (terraced wadi systems) are also found in the Negev in Israel (Evenari et al. 1961), in the Petra region in Jordan (Beckers et al. 2013), in the Matmata Mountain region in Tunisia (Hill and Woodland 2003), in Libya (Gilbertson 1986) and in Andalucia in Spain (Giraldez et al. 1988). In the United States, ponds are widely used for the purposes of irrigation, livestock watering, fish production, firefighting, and for storm water retention. Specifically, impoundments are used in South Florida on all new agricultural developments, for runoff control, water quality control, recharge of a shallow aquifer and other purposes (Clark et al. 1988; Dorota et al. 1990). In Ethiopia, the use of water harvesting technology for agricultural purposes dates to as far as the pre-Axumite period ( $\sim 560 \mathrm{BC})$ and there are evidences of remains of water harvesting in Gondar Castel built in the $15-16^{\text {th }}$ century for religious rituals of the king (Getachew 1999). Other water harvesting systems include terraced systems to harness runoff by the Konso community in the Southern part of Ethiopia.

\section{Background}

Evidence of climate change has already started appearing in Ethiopia in the increasing annual average minimum temperature throughout the country by $0.2{ }^{\circ} \mathrm{C}$ every decade over the last 50 years (MoWR 2001). This temperature increase has perhaps contributed to the increased frequency and severity of droughts in recent decades, resulting in food shortages and famine, spread of malaria into highland areas, loss of biodiversity, and a decline in wildlife number. The projected changes in climate and its variability would have serious implications on the natural resources, economy and welfare. The (FAO 2000) reported that the impacts of climate change and declining per capita agricultural capacity are expected to further threaten food security in the horn of Africa, including Ethiopia. MoWR (2002) also reported that about $67 \%$ of the country's landmass is categorized as arid or semi-arid lands, characterized by acute water shortage from erratic rainfall distribution and resulting in recurrent drought and famine. Due to the ongoing climatic change, the productive performance of the agricultural sector in Ethiopia has been very low. For instance, World Bank (2005) reported that agricultural GDP and per capita cereal production has been falling over the last 40 years with cereal yield stagnant at about 1.2 tons per hectare and the implications is that large areas of Ethiopia are plagued by food insecurity. A recent mapping on vulnerability and poverty in Africa (Thornton et al. 2006; Stige et al. 2006) placed Ethiopia as one of the most vulnerable to climate change with least capacity to respond. During this study period, the prevailing drought situation in the country has forced the Government of Ethiopia to draft a strategy for constructing more ponds in the effort to avail water at the household level for animal, human and agricultural purposes.

Bruins et al. (1986) defines water harvesting as the process of harnessing water for beneficial use with any 
kind of device or technique that collects, stores, and/or increases the availability of intermittent surface runoff and groundwater in drylands. Water harvesting is applied to irrigate crops and to supply water for animal and human consumption (Prinz 1994). Water harvesting techniques are distinguished as groundwater harvesting, runoff harvesting and floodwater harvesting (Beynes et al. 2006). Floodwater harvesting is also a technique that collects and stores water from ephemeral streams during flood events (Bruins et al. 1986).

Water harvesting systems are practiced in the semi-arid areas where mean annual rainfall is in the range between 400 and $600 \mathrm{~mm}$ (Getachew 1999). It has an advantage of providing water at or near the point where water is needed or used. Runoff water can be collected using structures such as rooftops, ponds, and flood plains. The harvested water can be used to supplement other water sources during dry periods and thereby relieving pressure on water sources. Water harvesting can also be used to supplement water sources during emergencies or water supply systems breakdown. Water harvesting systems constructions are low-cost since they can be constructed using local labor without requiring construction equipment.

It is not certain as to when the practice of pond construction began in the Oromia Region, but the practice is becoming common, especially in the low-land areas of the regions such as Borena, Bale, and Hararghe. In the Borena area, it was reported that a major change in rain patterns occurred in the $1960 \mathrm{~s}$ and ' $70 \mathrm{~s}$, which prompted NGOs (such as World Vision) to begin ponds construction (Cerritelli et al. 2008; Debesu 2013).

In view of this, the Regional Government, through its line organization, Oromia Irrigation Development Authority (OIDA) before and Oromia Bureau of Agriculture and Rural Development (OBARD) currently, has been implementing such ponds to render the services discussed above. To mention some, at the end of the budget year of 2003, OIDA planned to construct 83,400 ponds as a household irrigation package. Out of this, it was reported that the construction of 45,596 ponds were completed (OIDA 2004). Moreover, according to the information obtained from OIDA's Extension department, 196,070 ponds were planned for construction in 2004 budget year for supplementary irrigation on 5,882 hectares. Out of the plan for the same year, the construction of 78,843 ponds which enables supplementary irrigation of 2,365 hectare was completed. Moreover, it was planned to construct 221,767 ponds in the year 2005 in 14 zones of Oromia region. The detail of the 2004 accomplishment is shown in Table S.1.

Uses of harvested water in the area. The water that has been harvested around this project area is being utilized for different purposes such as watering domestic animals, washing purposes, and even for human consumption in time of great need (Figure. 2.1).

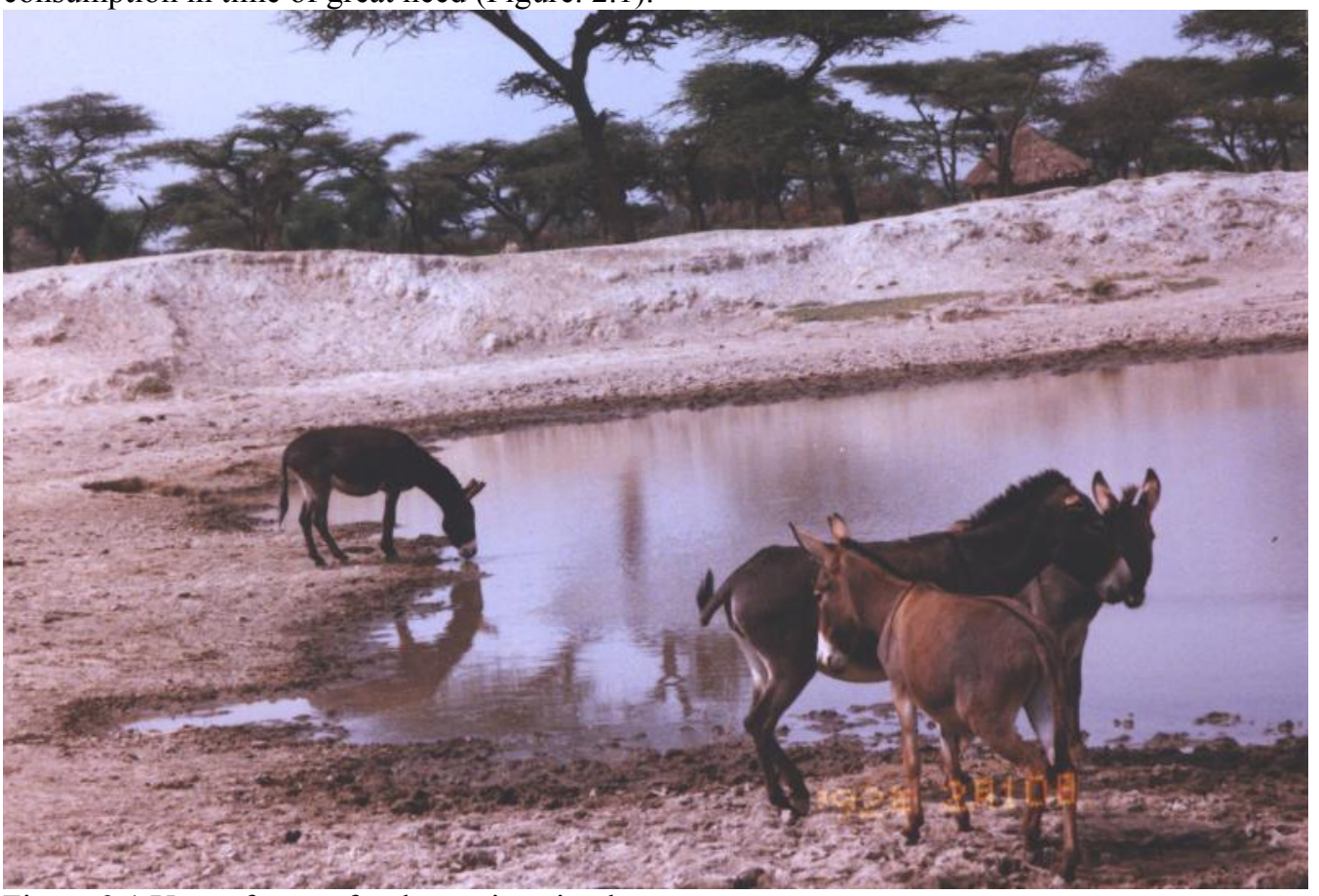

Figure 2.1 Uses of water for domestic animals

In this project area, the harvested water was also being utilized in the fabrication of hollow mud-blocks, a source of income for the owners of the pond (Figure. 2.2). However, this income-generating project has never fully developed due to the excessive seepage losses and short holding times for stored water in the ponds. 


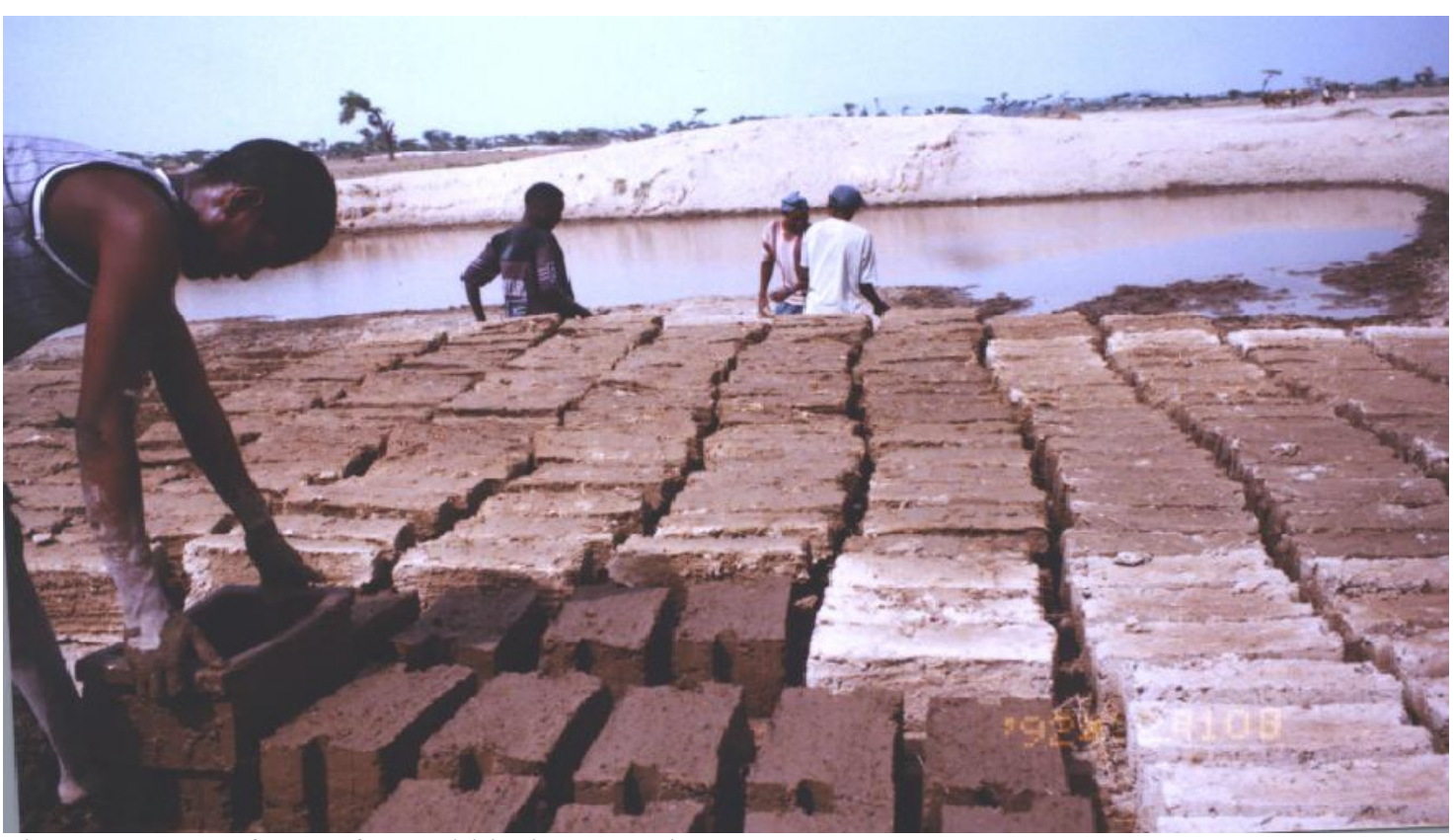

Figure 2.2 Uses of water for mud-block preparation

Problems associated with ponds. The effort to develop more ponds in the region couldn't be more problemridden. The most common problems with most of the ponds constructed so far are their excessive seepage and bank instability. Since some of the areas where ponds are often constructed are too permeable to hold water, excessive seepage losses are a bottleneck. However, in some cases the strong localized demand for water can necessitate such a site selection.

For example, out of the ponds constructed in the year 1996, it was observed in the Bale zone of Oromia region that only $13.8 \%$ could contain water. Similarly, in Arsi Zone, only about $24 \%$ could contain water. Generally, out of the total ponds of 78,843 constructed in the year 1996 , only 31,987 or $(40 \%)$ could store water (Table S.1). The main problem that can be raised here for poor storage of the ponds is the problem of excessive seepage from the ponds. Hence, methods of design and construction should be sought so that these problems are resolved, and more ponds can be implemented in this endeavor.

Objective of the study. The objective of this study is to investigate and compare four cost-effective methods of supplementary irrigation pond construction. The methods were chosen based on the expected ability to hold water, availability of local materials, and traditional knowledge of local farmers. To this end, the study evaluates the suitability of proposed alternatives, quantifies the water tightness, and compares cost of construction of the treatment methods for sealing ponds.

\section{Methodology}

The Adami Tulu Jigdo Kombolcha site was deemed appropriate for this study because i) the soil of the area is sandy textured and will thus not have a natural tendency to hold water, and ii) the site has a topography that can likely generate the required runoff to fill the ponds. The runoff water from the catchments was guided to the pond by placing stones and soil piles in the direction of the runoff and then conveying it to the pond using an earthen canal. Four ponds each of $126-\mathrm{m}^{3}$ capacity were excavated and four different methods of achieving water tightness were tested and compared. The amount of seepage from each pond was recorded following the filling by accessing and reading the water-level staff gauge on an hourly basis. Hourly day and night time measurements were made to record the level drops and thereby study the impact of evaporation.

The research project is in Oromia Region, Arsi Zone, Adami Tulu Jigdo Kombolcha District, and Kemo Gerbi Peasant Association (PA's) (Figure 3.1). It is located at $3 \mathrm{~km}$ east of Batu town which is the center of East Shewa Zone. Its specific location lies at Geographic coordinate of $7^{\circ} 55^{\prime} 50^{\prime \prime} \mathrm{N}$ Latitude and $38^{\circ} 41^{\prime} 20^{\prime \prime} \mathrm{E}$ longitude. The average altitude of the project area is 1660 meters above mean sea level (m.a.m.s.l). For schematic layout of the project area, refer to Figure 3.2. The four ponds are labeled as P1 through P4, and the catchment area is the total sub-watershed which is channeled into the ponds via the constructed drainage way. 


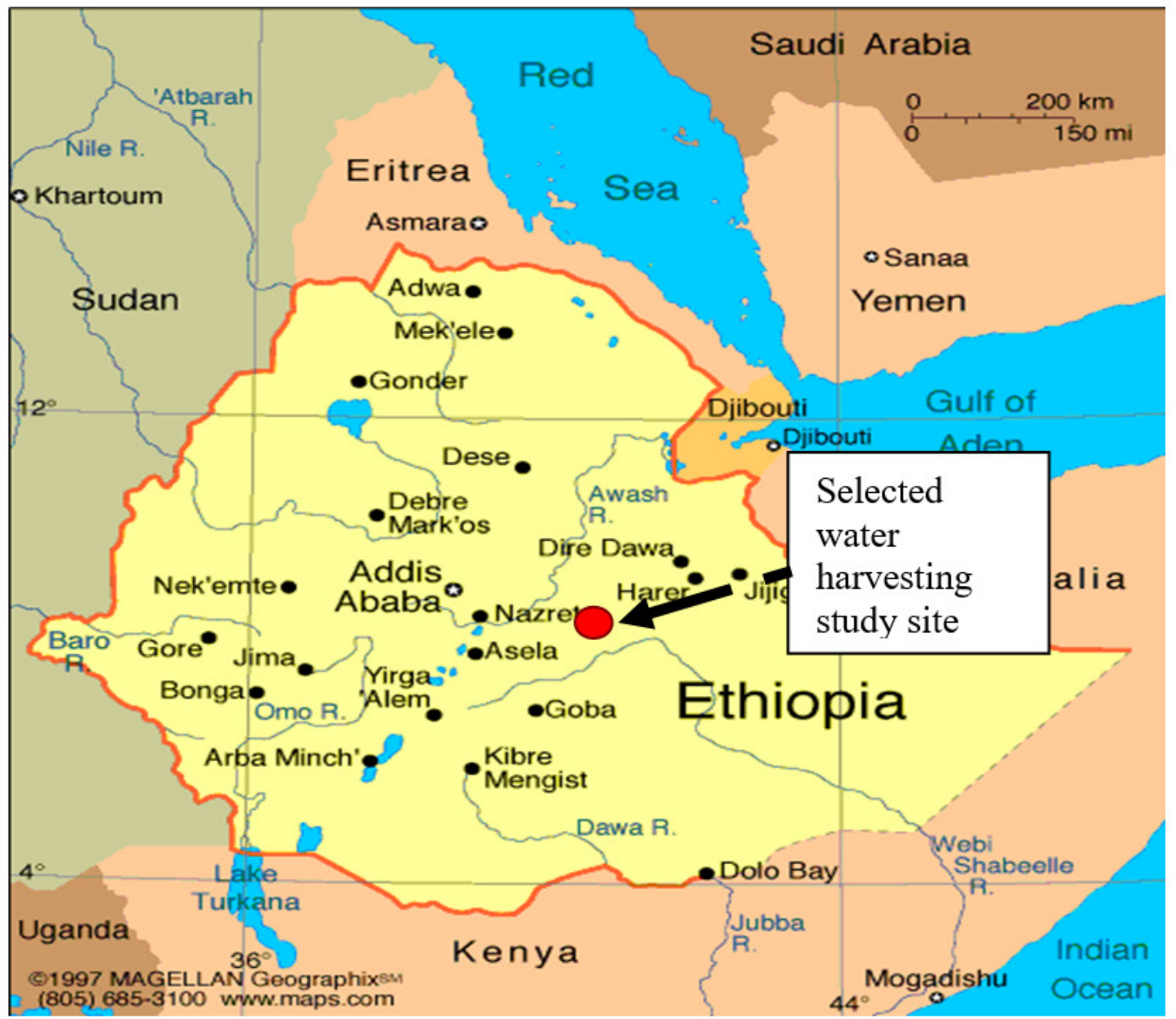

Figure 3.1: Location map of the water harvesting site

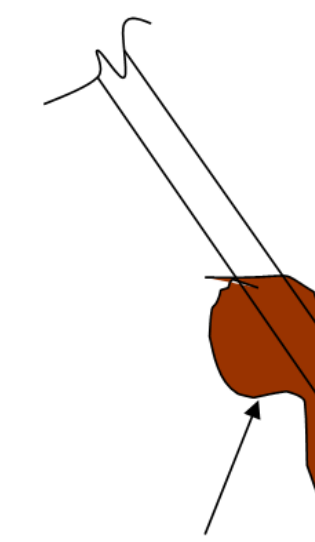

Batu Town

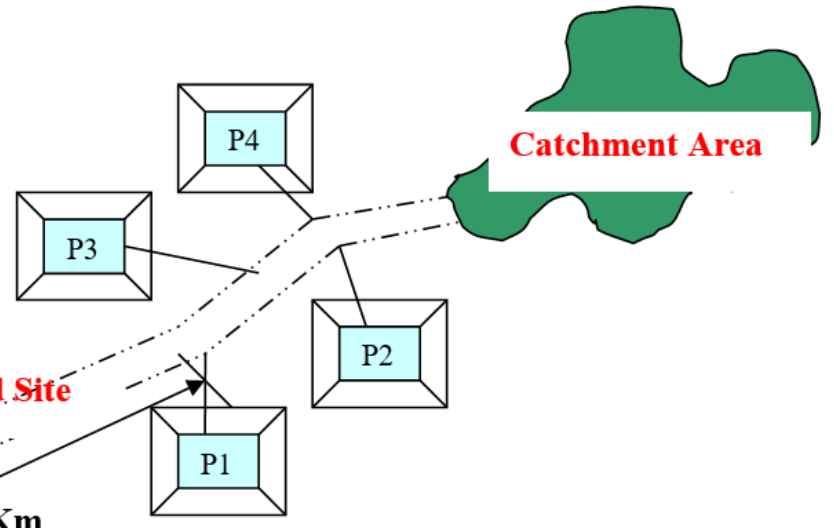

Addis - Shashemane

Road

Figure. 3.2: Schematic layout of the project area ("P" = pond). 


\subsection{Pond Design, Construction and Stabilization Approaches}

Design of the pond

The design of the pond was made by considering the optimum volume of the pond that would be enough to undertake the proposed study. Since the natural topography of Kemo-Gerbi Area lacks significant differences in elevation, excavation is the most appropriate method considered for the design of water impoundment.

The volume of excavation required was calculated using the following expression for a trapezoidal volume:

where

$$
\mathrm{V}=\frac{D(A+4 B+C)}{6}
$$

$\mathrm{V}=$ total volume of excavation $\left(\mathrm{m}^{3}\right)$

$\mathrm{A}=$ pond top area $\left(\mathrm{m}^{2}\right)$

$\mathrm{B}=$ pond area at half-depth level $\left(\mathrm{m}^{2}\right)$

$\mathrm{C}=$ pond bottom area $\left(\mathrm{m}^{2}\right)$

$\mathrm{D}=$ depth of the pond $(\mathrm{m})$

The volume of the pond required was fixed based on the amount of water needed to supplement crop failure during peak periods of water requirement by crops. The design parameters of the ponds are as shown in Figure 3.3 below. The pond so designed was therefore made to have a total volume of $126-\mathrm{m}^{3}$ at depth of full pond. A $20 \mathrm{~cm}$ earth fill around the pond was provided to serve as a free-board.

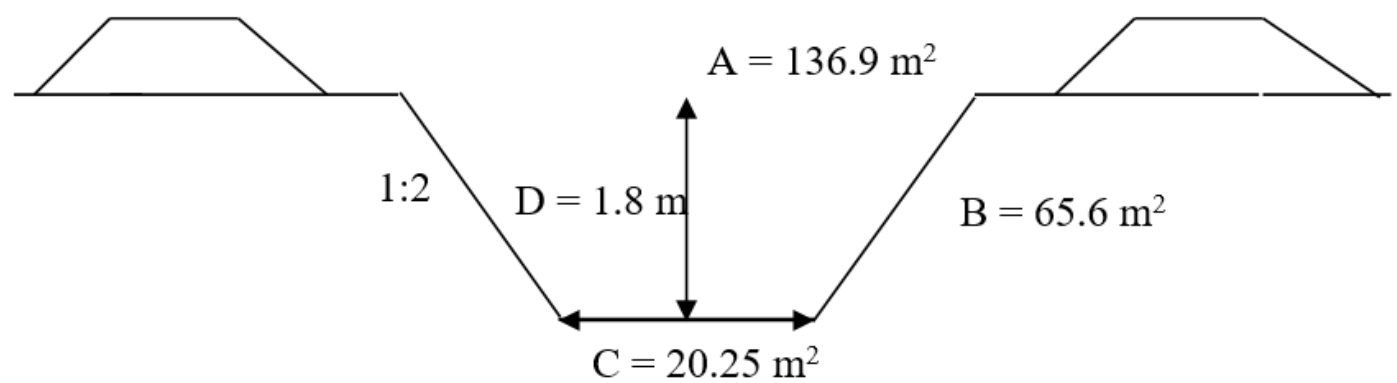

Figure 3.3: Cross section of the pond. Each pond was constructed with the same dimensions.

\section{Construction of the pond}

The construction of the pond was made after clearing and removing of the weeds in the proposed pond site using local labor. After carefully laying out the pond dimensions on the ground using a rope, pegs and line level, excavation was made on the bottom area and sides walls of the pond. Treatment of the sides slope (trimming or cutting) was made using a spade with the help of a rope as a guide. The pond construction process by the methods discussed above is shown in Figure 3.4.

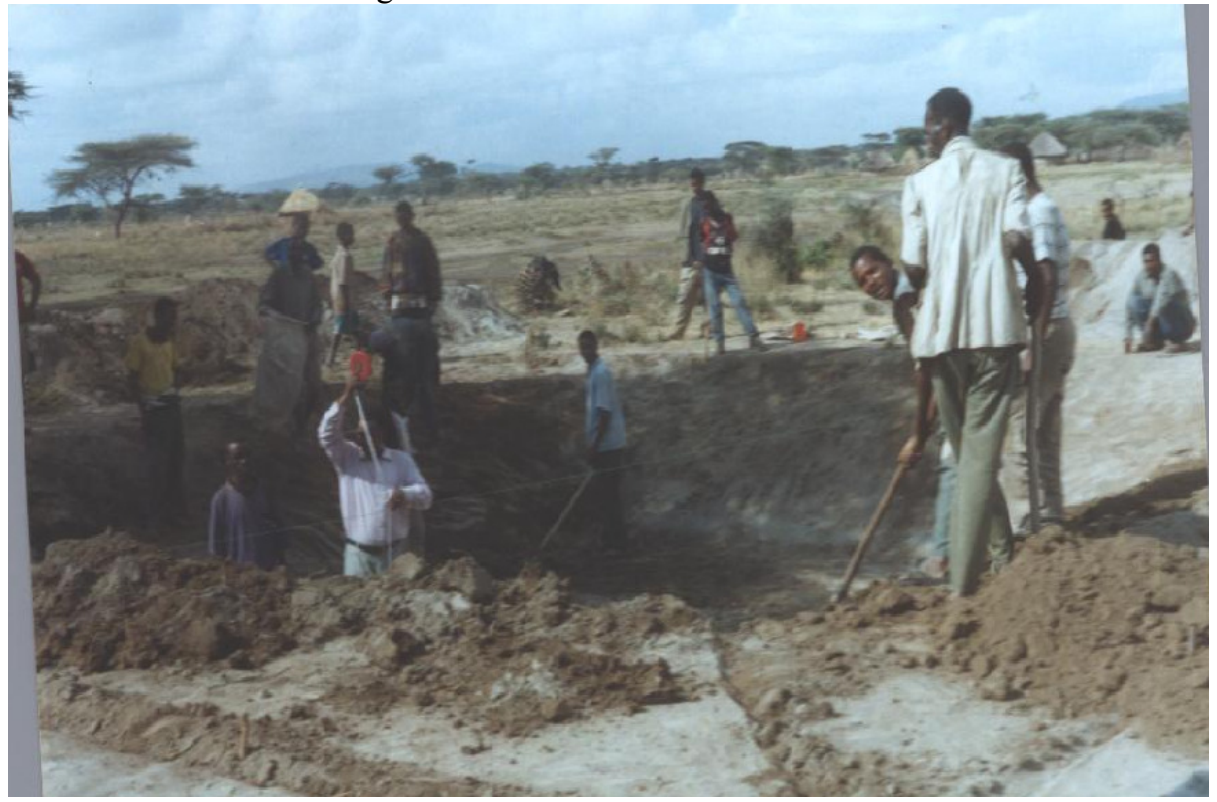

Figure 3.4: Pond excavation control 


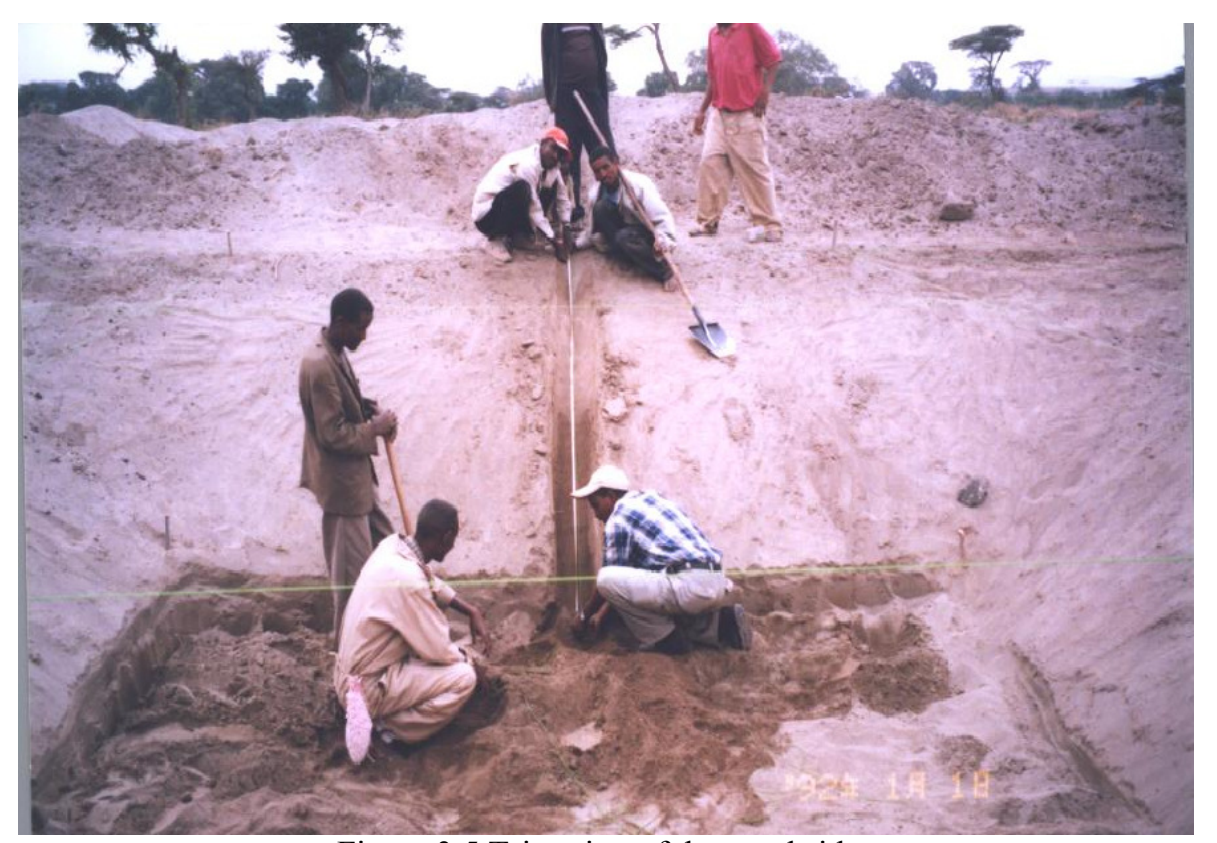

Figure 3.5 Trimming of the pond sides

\subsection{Treatment of the pond}

The treatment of the ponds was made as per the treatment materials and methods proposed in this study. The four treatments proposed in this study are i) control, ii) compaction, iii) termite-mound and iv) a soil-straw mixture. The treatments are made in the following fashion:

\section{a). Control}

One of the ponds was left untreated (just as excavated) so that it could be used as a control. Finishing of the pond sides and bottom was made carefully in such a way that compaction of the pond is avoided.

\section{b). Compaction}

One of the methods for the attainment of water tightness in ponds is compaction. Since the soil material of the site is well graded from small gravel or coarse sand to fine sand and silt, the pond can be made relatively impervious by compaction alone. Prior to compaction, the soil was cleared of all vegetation and holes and crevices were filled with uniform material. Here all debris and pieces of tree roots were removed. The loosened soil was compacted to dense, tight layer using a manual compaction tool made from a wood / cement paste poured into a can. The pond compaction was made after watering the bed and side slopes of the pond and tamping it using the compaction tool prepared on the site. The thickness of the compacted liner was approximately $10 \mathrm{~cm}$ after compaction. An extra $10 \mathrm{~cm}$ was excavated at both the sides and bottom of the pond to be eventually filled by compaction. The watering of the pond and the compaction process is shown in Figure 3.6. 


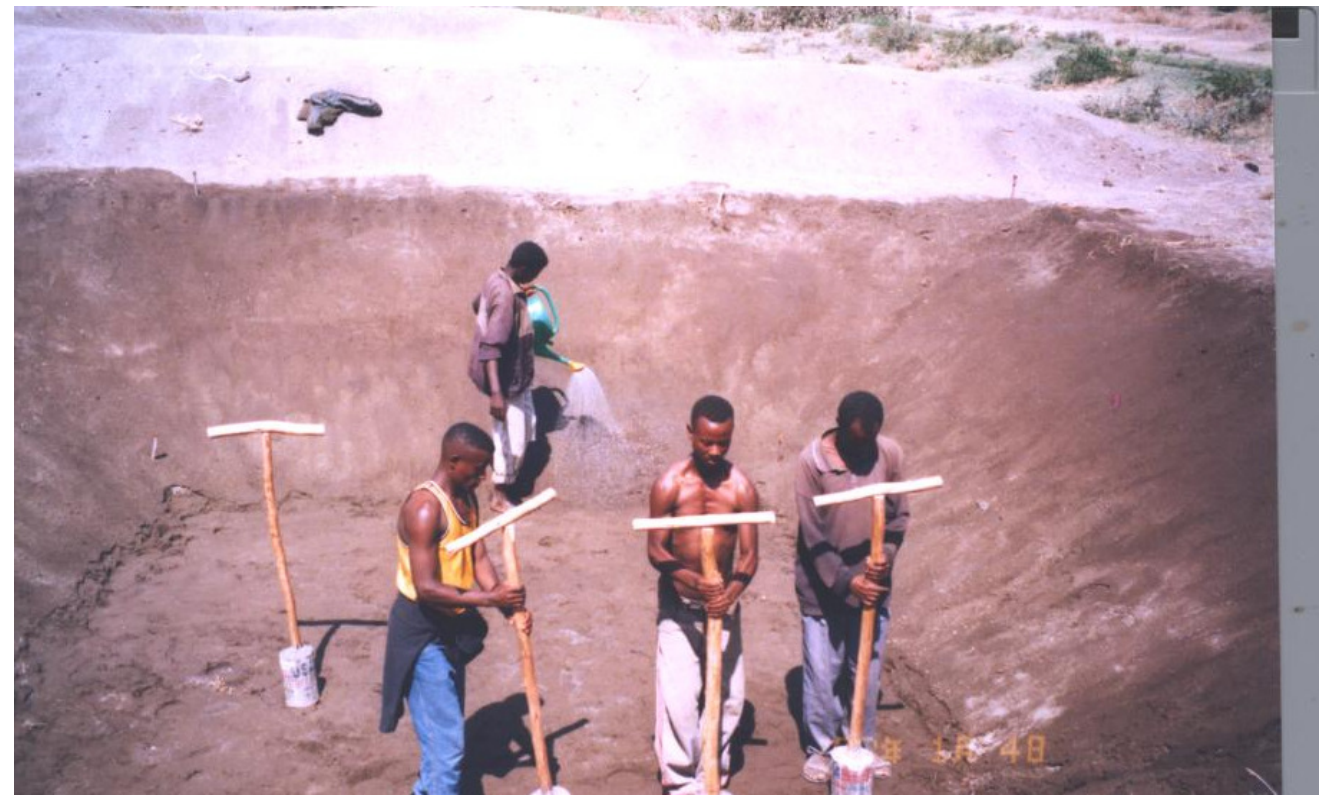

Figure 3.6 Compaction of the pond

c). Termite mounds (kuyisa)

Traditionally, termite-mound has been used as one of a sealing mechanism of ponds. The termite mound is prepared by soil microorganisms (termites) by bringing soil from a deeper layer and mixing it with their secretion to bind the soil particles together. Local farmers acknowledge that the soils prepared by so doing was found out to be watertight. Hence, termite mound (kuyisa) was selected as one of the treatments materials (Figure 3.7).

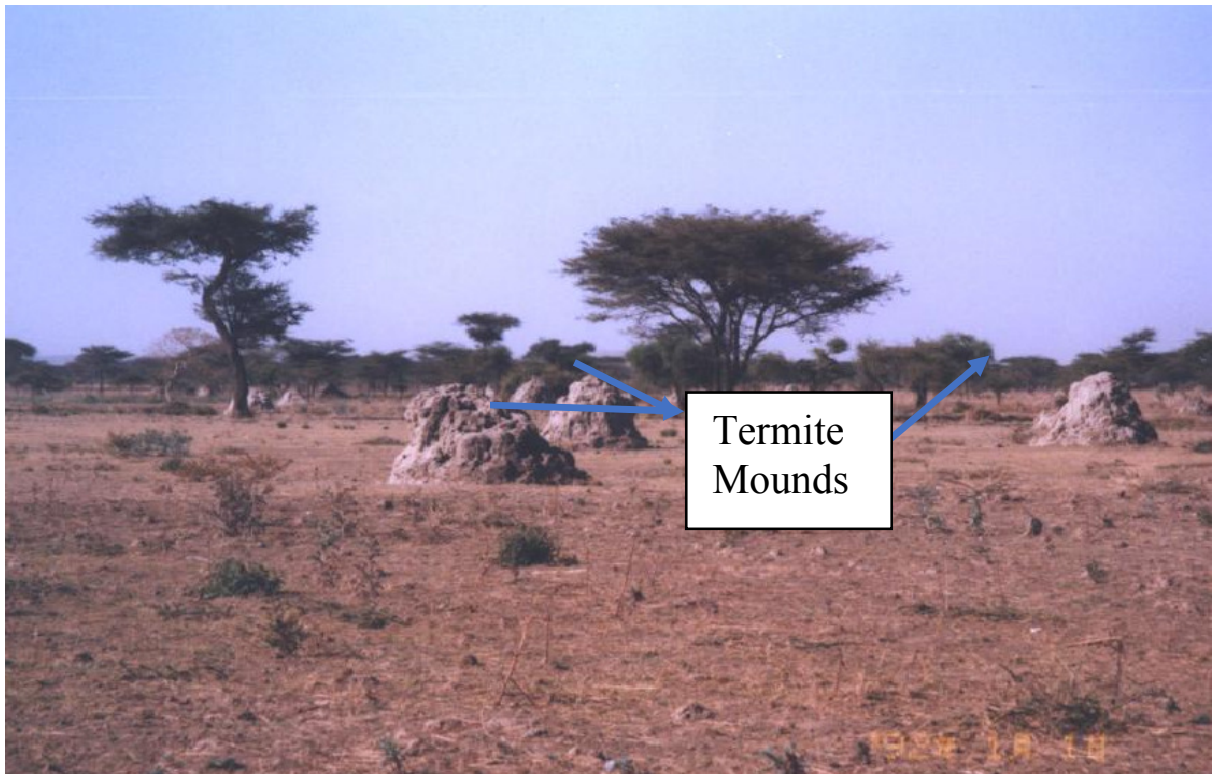

Figure 3.7 Termite Mounds for treatment

Treatment of the pond with a termite mound needs a very careful construction process as it is going to be constructed on the side slope of the pond (there should not be caving of the treated bank material). Hence, before the treatment begun, the side and the bottom of the pond were compacted. Then a contour was made on the sides of the pond to prepare it for putting the termite mound on the side to prevent the amendment material from falling into the bed of the pond. The treatment technique is shown in Figure 3.8, 3.8.1 and 3.8.2. The thickness of the mound material used was approximately $10 \mathrm{~cm}$ upon compaction. 


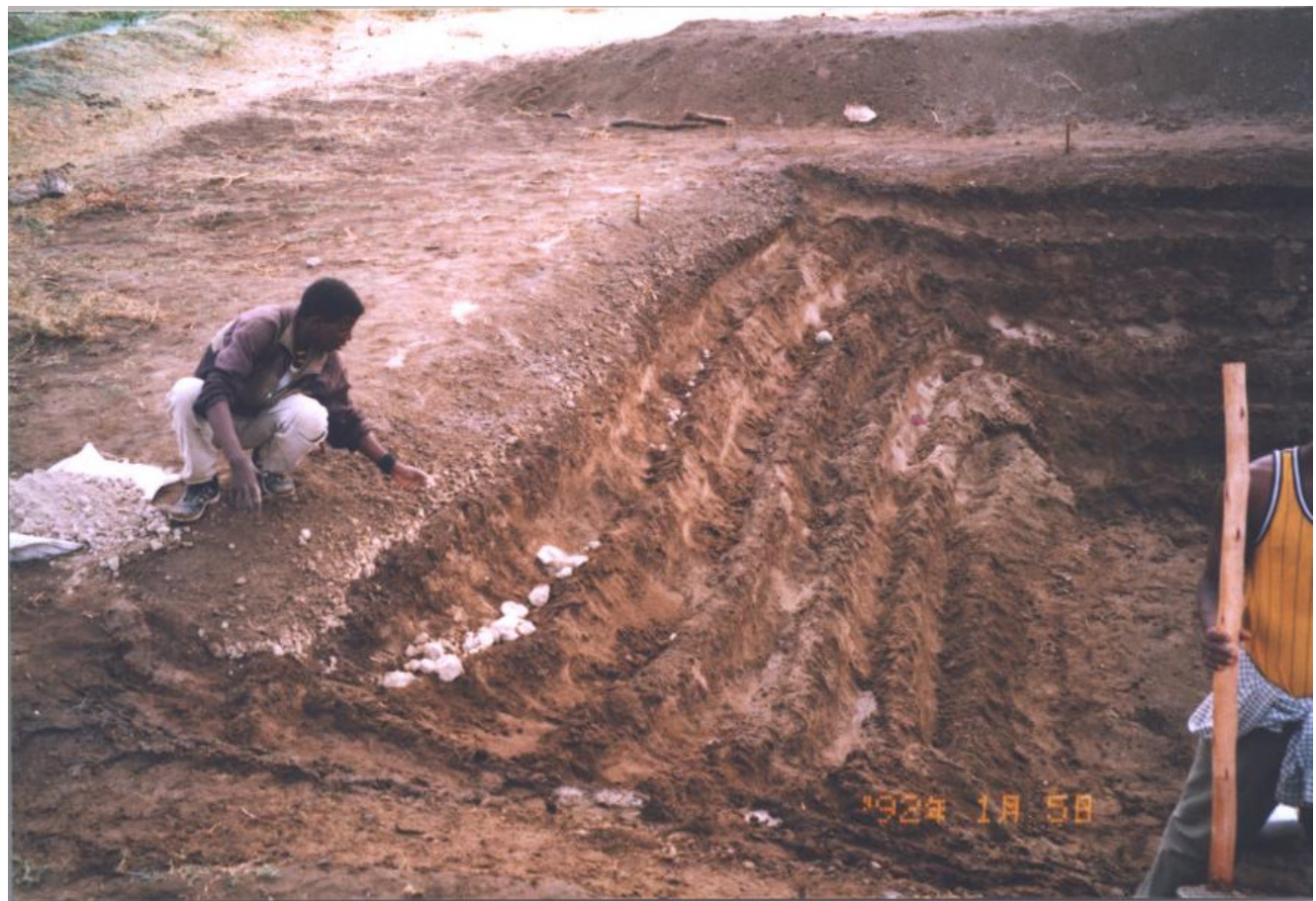

Figure 3.8 Treatment by Termite-mound

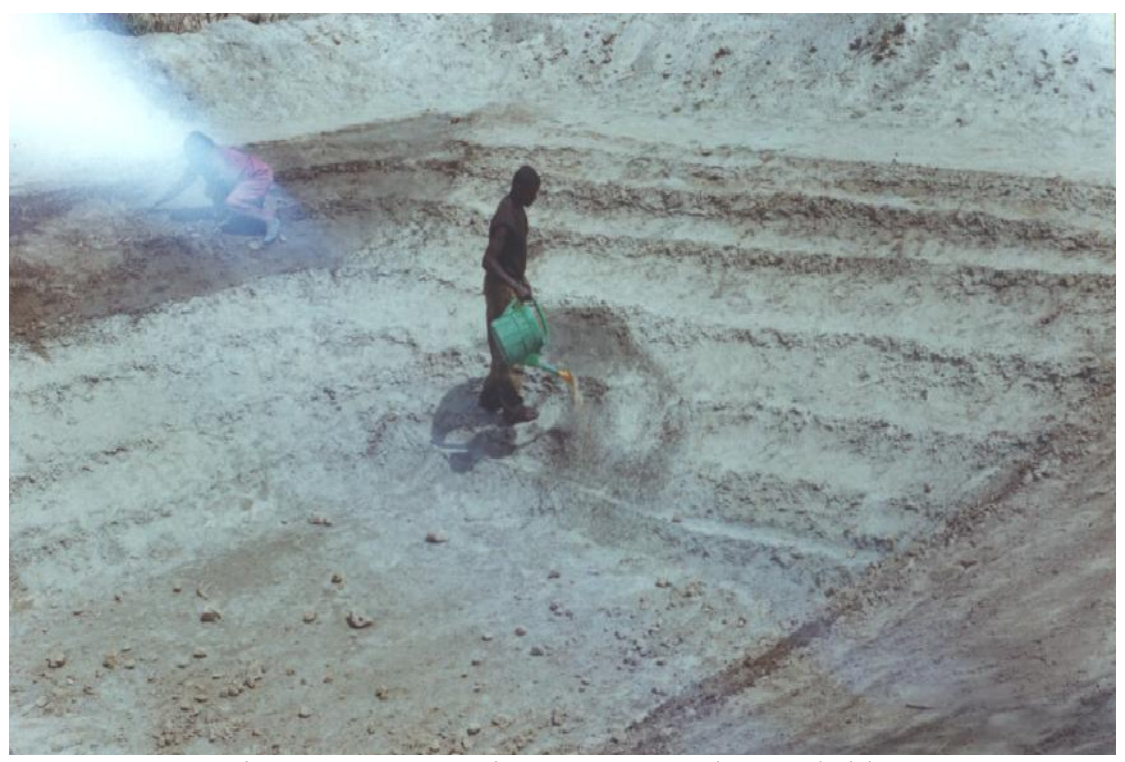

Figure 3.8.1 Preparing terraces on the pond sides 


\section{d). Soil-Straw mixture}

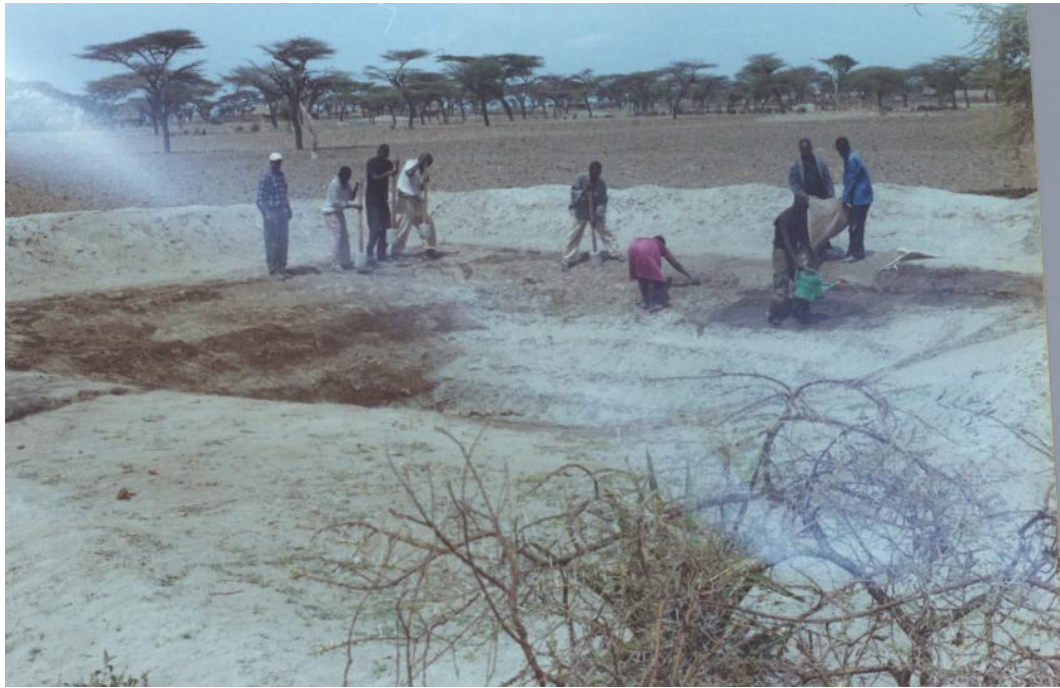

Figure 3.8.2 Treatment by termite mound and compaction

The soil: straw mixture was a final treatment method used in this study. The soil used in this treatment is obtained by excavating a clay loam soil about $4 \mathrm{~km}$ distance from the pond site. About $15 \mathrm{~m}^{3}$ of soil was transported using a double cabin pick-up truck for this purpose. The straw added to the soil was obtained from a local market. The local crop, teff straw, was selected for this purpose as it can be easily mixed with mud and is very common in the region. The infiltration rates of the selected soil were tested in the field by digging $10 \mathrm{~cm}$ diameter and $30 \mathrm{~cm}$ depth hole, filling it with water and evaluating its impermeability through measuring the draw-down over 3 hours. The soil-straw mixture was prepared by local labor in a similar fashion as that of the plastering of houses to build a mud wall. The soil-straw mixture prepared was cured for 3 days to have a good mix. The process of preparing the soil-straw mix is shown in Figure 3.9.

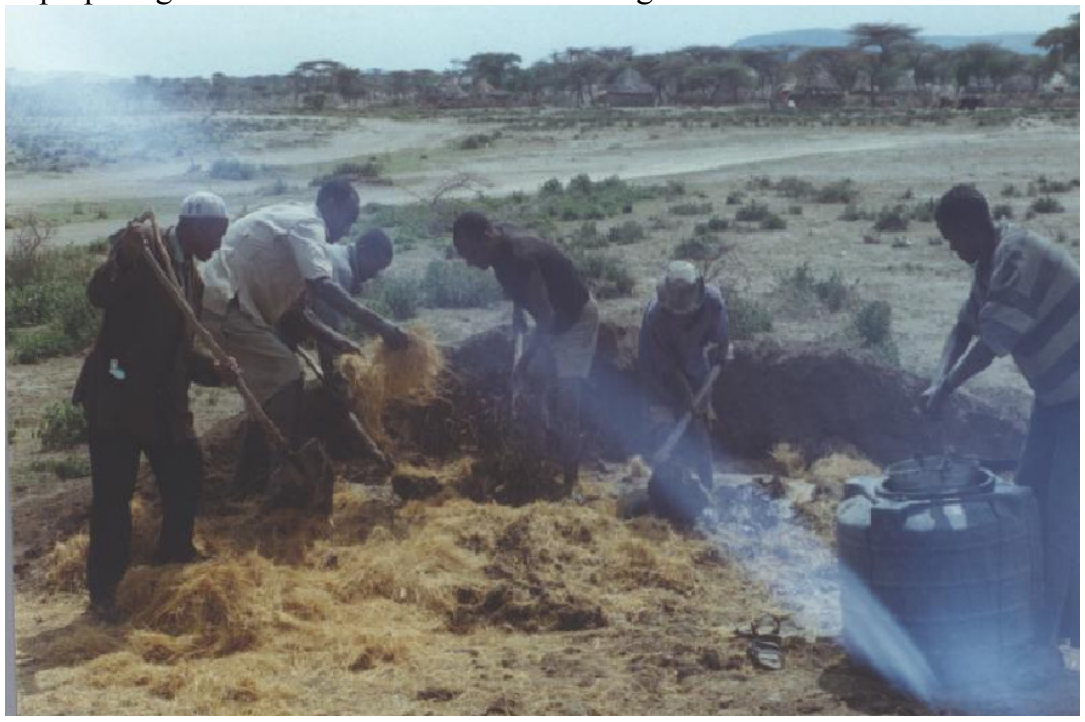

Figure 3.9 preparation of the soil-straw mix

The treatment was applied by:

- Watering the excavated and finished surface of the pond both on its sides and bottom.

- Making a hole into the side slope using a wooden stick to create good bond between the pond and the treatment material by getting the material forced into the hole.

- Applying the soil: straw mixture or plastering the pond surfaces in the same way as the traditional mud plastering (Figure 3.10) 


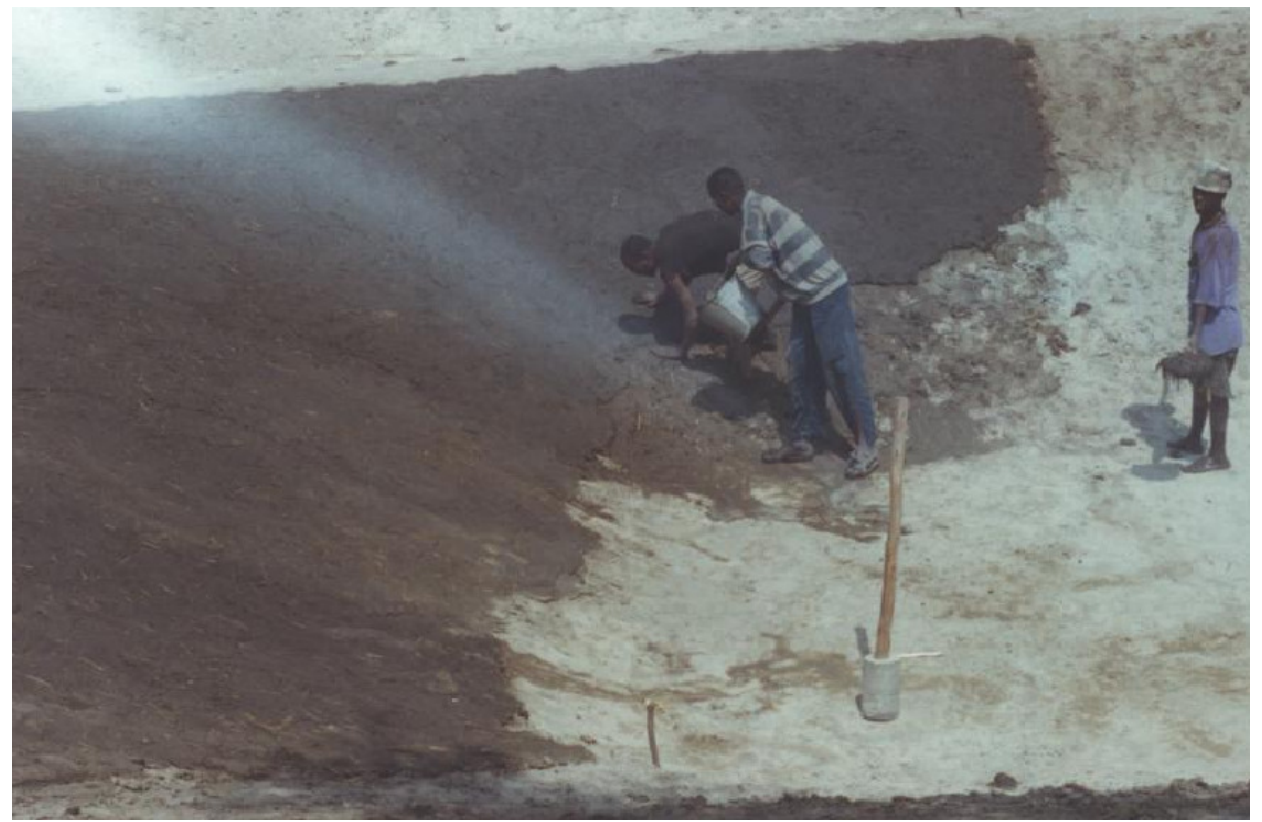

Figure 3.10 Treatment by soil-straw mixture

After the necessary construction work is completed, the pond is fenced with a locally available material to prevent the pond from being accessed by children and domestic animals. The fencing done in this case is shown in Figure 3.11.

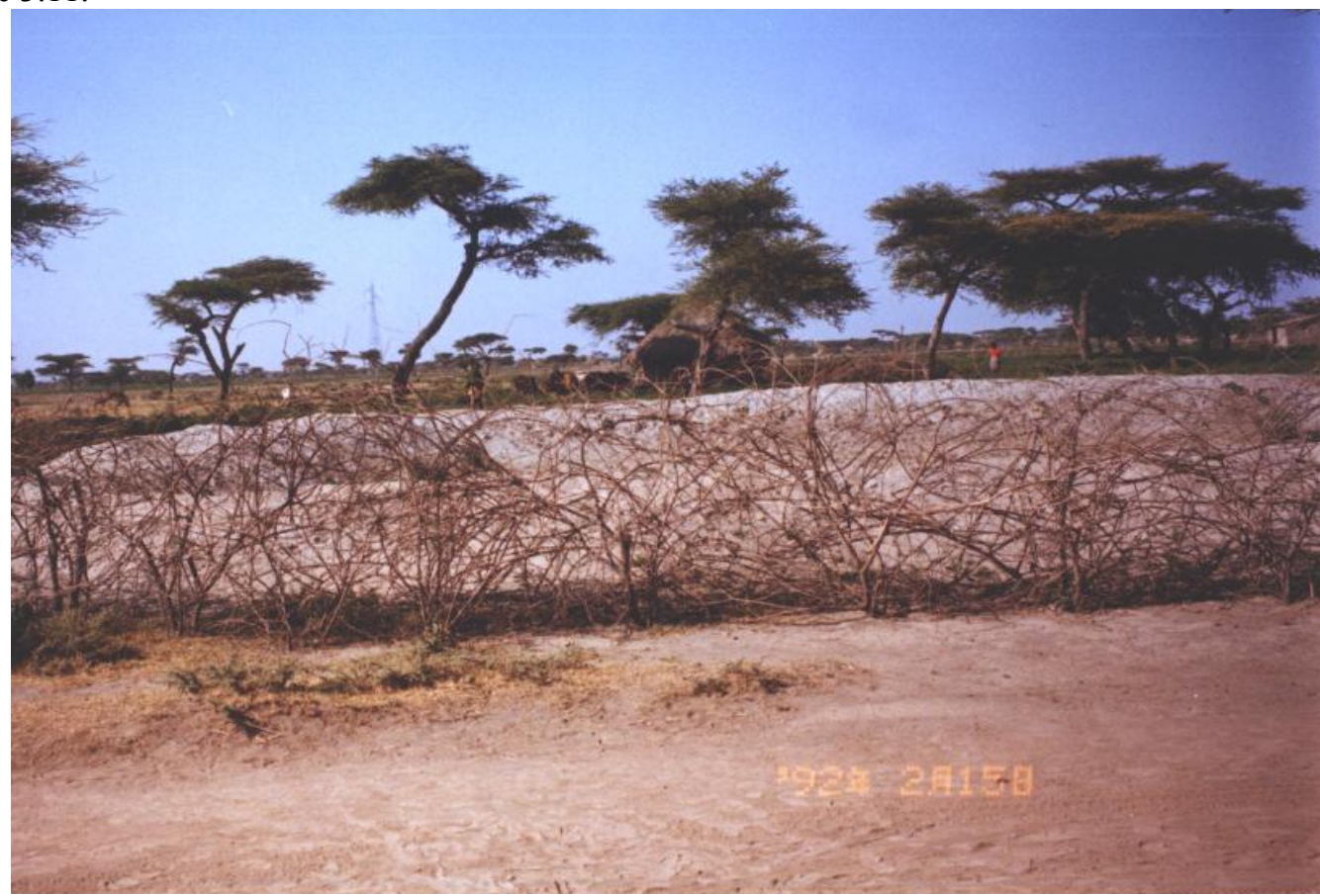

Figure 3.11 Fencing of the pond (typical of all four ponds).

Water level measuring instruments; Four steel staff gauges were prepared in a local workshop, marked with gradation, and installed to measure the drop of water level in each pond. The gauges have a total height of $2 \mathrm{~m}$ and are anchored into the pond bed with a $25-\mathrm{cm}$ extra steel buried in the pond bottom using a concrete mix. The top levels of the gauges were kept at a uniform level above the ground to accurately measure the level drop within the ponds.

\subsection{Water filling of ponds}

The ponds were fully constructed before the beginning of the rainy season in 2005. After completion, the ponds were filled by guiding runoff water from the upland catchments into the ponds simultaneously using the canals constructed for this purpose. Desilting basins (silt trap basin) of $2 \mathrm{~m}$ wide, $2 \mathrm{~m}$ long and $0.5 \mathrm{~m}$ deep were constructed about $3 \mathrm{~m}$ upstream of each pond to prevent silt load from entering the ponds. Prevention of the bank 
erosion during the pond filling was overcome by using a staircase-type water channel, which was constructed to serve this purpose. The staircases have another benefit of serving as a means (a walk way) to abstract water from the pond (Figure 3.12).

The filling of the ponds and level measurement is shown in Figure 3.13. All the ponds were filled to the same initial depth of $175 \mathrm{~cm}$, so that the initial static head level would be the same.

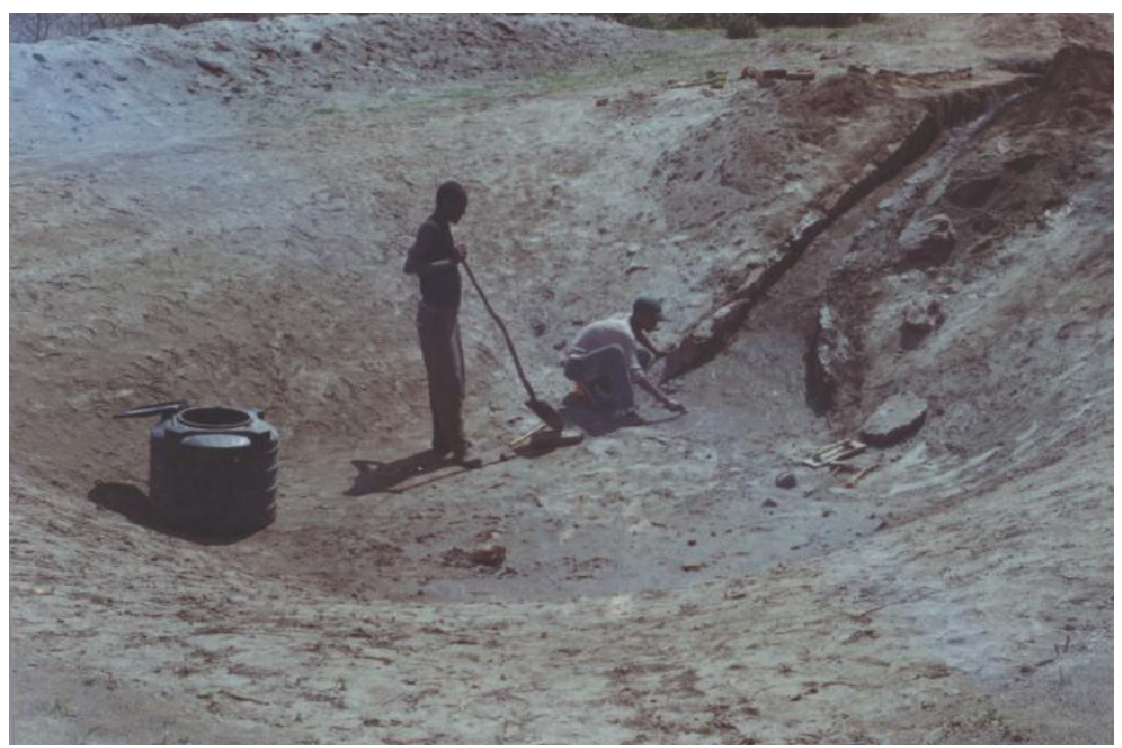

Figure: 3.12 Pond inlet and the staircase

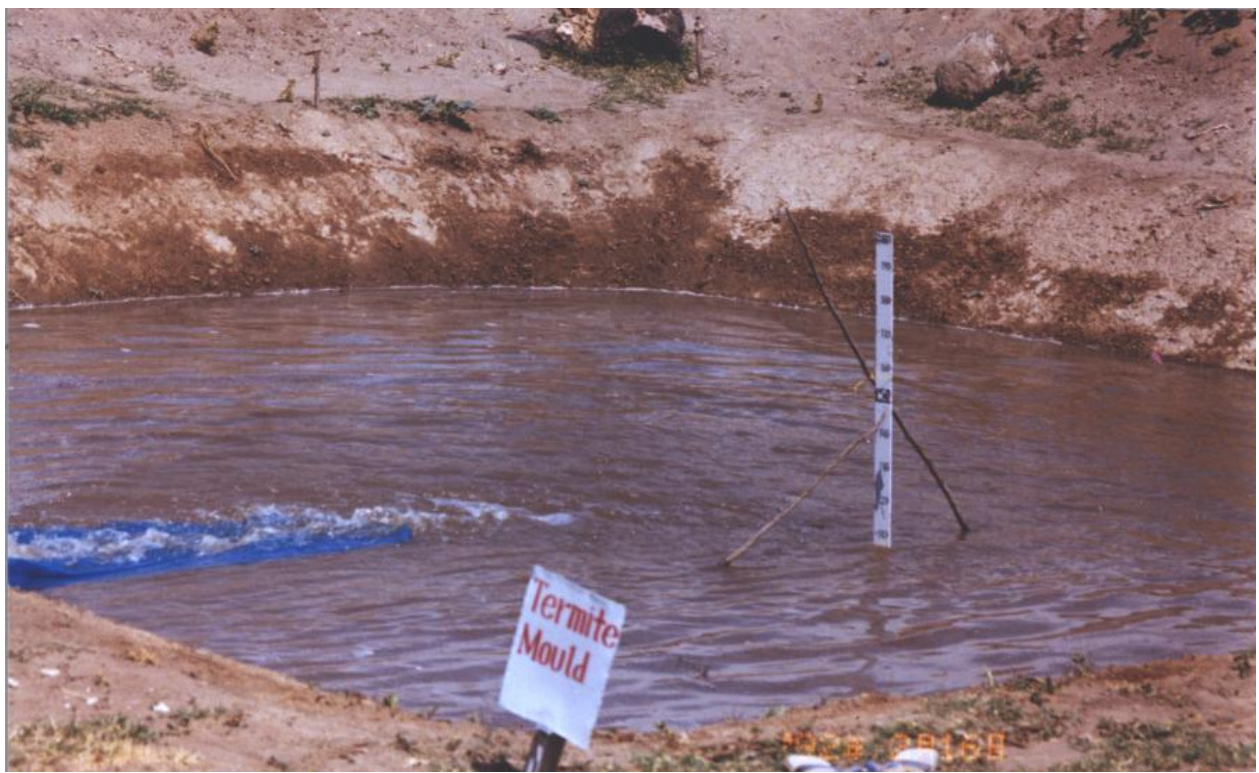

Figure 3.13 Pond filling \& staff Gauge

\subsection{Cost comparison of the pond treatment methods}

Different methods of sealing ponds have been traditionally applied in this country. However, the costs that are incurred to undertake some of the common treatment methods have not yet been estimated. As a result, it has not been possible to select the low-cost method out of the different alternatives available. Therefore, the expenditures made in undertaking the different treatment method for sealing ponds were recorded and are presented here. (Cost breakdowns for each treatment are given in Table 1.)

\section{Cost of Control pond}

The cost of constructing the control pond is only the cost of excavation (Birr 150), which is a common cost to all the other types of ponds. Hence it can be said to be the baseline / low-cost pond as compared to the other ones. 


\section{Cost of Compacted Pond}

Compaction differs from the control in that it includes the compaction of the excavated natural material. Hence, no extra soil is utilized for handling the compaction works. In other words, only the natural excavated soil is compacted to bring soil particles more together to increase their impermeability. The cost of soil compaction was 256-Birr for labor cost for compaction and 50 Birr for purchase of water, which brings the total cost of compacted pond 456 Birr (including the excavation cost).

\section{Cost of Termite-mound pond}

The cost of termite-mound treatment involves the excavation of the mound, its loading and transportation from 2 $\mathrm{km}$ distance and finally its compaction by applying water to the surface of the soil to be treated. The total termite-mound lining thickness considered in this study is $10 \mathrm{~cm}$. The total volume of treatment material is therefore, $15 \mathrm{~m}^{3}$. The total cost of lining using termite mound is Birr 850 .

\section{Cost of Soil-Straw Mixture pond}

The cost of treating the pond with a soil-straw mix involves the excavation and transportation of the soil, which has lower permeability from about $2 \mathrm{~km}$ from the pond site, mixing the soil with straw to create better bondage and improving the quality of sealing. The thickness of sealing in this treatment method is $10 \mathrm{~cm}$. The total quantity of the treatment material in this case is $15 \mathrm{~m}^{3}$. The total cost of lining the pond using soil- straw mix is Birr 750.

Table 1. Costs associated with four pond treatment methods (1 \$USD 19.5 Birr)

\begin{tabular}{|l|c|c|c|c|}
\hline \multicolumn{1}{|c|}{ Tasks } & $\underline{\text { Control }}$ & $\underline{\text { Compacted }}$ & $\underline{\text { Termite-mound }}$ & $\underline{\text { Soil-straw }}$ \\
\hline Excavation & 150 & 150 & 150 & 150 \\
\hline Loading/Unloading & & & 100 & 100 \\
\hline Application of treatment & & 256 & 400 & 400 \\
\hline Materials (straw, termite-mound) & & & 150 & 50 \\
\hline Water for compaction & & 50 & 50 & 50 \\
\hline \multicolumn{1}{|c|}{ Sub-total (Birr) } & $\mathbf{1 5 0}$ & $\mathbf{4 5 6}$ & $\mathbf{8 5 0}$ & $\mathbf{7 5 0}$ \\
\hline
\end{tabular}

\section{Data Collection}

Once the pond filling was completed, the next step was collecting data, performed by a data collector that was employed for this project. Hourly drop of level in "cm" at an hour interval was recorded for the daytime. Moreover, to study the effect of evaporation, night-time measurement was made for 12-hour time periods over 5 consecutive days. The mean pan evaporative rate in Ziway area was reported as $142 \mathrm{~mm}$ per month (Melesse et al. 2009). The rate of evaporation from all the four ponds was assumed to be equal though there might be some discrepancies that may result from the level drops. This is because, as the level drops are different in all the treatment methods the ponds which contains more water has more surface area and hence a little bit higher evaporation than the ponds leaking/allowing more seepage.

\section{Results and Discussion}

The data collected from the research project is analyzed to arrive at better understanding and conclusion of the study. Based on the result obtained from the study, the hourly seepage (percolation) losses from all the treated ponds were plotted. The pond filling time was selected considering the rainfall pattern of the area i.e., at the end of the rainy season. Evaporation loss was measured using pan evaporation method and it was assumed that all the four ponds experience same out and thus not considered in the analysis. The average temperature of the region is $19.2{ }^{\circ} \mathrm{C}(\mathrm{MoA} 2000)$.

The data collected is graphed to compare the amount of the level drops from all the four ponds. Figures 4.1 and 4.2 are used as a summary to analyses the results obtained. The analysis made for all the ponds are summarized as follows:

\section{Control pond}

Water level drop from the pond used as a control reached an amount of $149.5 \mathrm{~cm}$ from the total filling height of $175 \mathrm{~cm}$ only in the first day of the filling which is $15 \%$ of the total storage level. This means there is a level drop of $25.5 \mathrm{~cm}$ in only the first day of the filling. This level drop continued for the next three days. The level drop becomes $15 \mathrm{~cm} /$ day on average starting from the fourth to the seventh day and then reaches an average level drop of $8 \mathrm{~cm} /$ day for the remaining periods. Eventually, complete drying of the pond could be observed right after the ninth day. 


\section{Compacted pond}

The drop of water level from this pond reached $17.5 \mathrm{~cm}$ from the total filling height of $175 \mathrm{~cm}$ only in the first day of filling. This amounts to about $10 \%$ of the original water level. The decrease in the water level continued for next 5 days with an average daily drop being $11.5 \mathrm{~cm}$. The level drop remains constant over the subsequent 11 days with an average being $5.5 \mathrm{~cm} /$ day. The pond contained half of the filling level for about 7 days ( 1 week). The overall duration that the pond contained water is about 17 days.

\section{Treatment using termite mound}

The drop of water level in the pond in the first day of filling is $12 \mathrm{~cm}$. It means that the stated amount of water height is lost through percolation, filling of pores of the treatment material and partially through evaporation loss. The drop of level from this pond continued to reduce for the next two days with a daily amount of $7.9 \mathrm{~cm}$. It continued to drop by an average amount of $3.4 \mathrm{~cm} /$ day starting from the fourth to the ninth day after the first filling, and then after reaches a constant amount of level drop of about $2 \mathrm{~cm} /$ day on average for the remaining periods. The pond contained half of the total filling height for about 15 days. The ponds reached $50 \%$ of the level drop of the original fill height of $175 \mathrm{~cm}$. It could contain water for 43 days.

\section{Treatment using soil-straw}

In this pond, the drop of water level on the first day of filling reached an amount of $165 \mathrm{~cm}$ from the initial filling height of $175 \mathrm{~cm}$, which is $10 \mathrm{~cm}$ level drop and this level drop continued with the same amount every day up to the third day. The average level drop starting from the fourth day to the sixth day was found out to be $6.5 \mathrm{~cm} /$ day. Then after, it continued to drop with an average amount of $1.75 \mathrm{~cm} /$ day starting from the $7^{\text {th }}$ to $47^{\text {th }}$ day after filling. Furthermore; it could be observed that this pond contained water for 47 days, which is about 7 weeks.

The result of the study is further analyzed to observe the volume of water stored within all four ponds and is shown in Figure 4.2. From this Chart it could be observed that $50 \%$ of the water stored could be lost within 4,7 , 15, and 19 days for the control, compaction, termite mound, and soil: straw treatments, respectively. The amount of the water stored in the pond in cubic meter was calculated by multiplying the water depth in the pond and the water surface area.

From the discussion made above it can clearly be seen that the pond which was used as a control has greater maximum drop of water level than all the other methods of treatments considered in the study. It could lose $15 \%$ of the total amount of water just within the first day of filling. The compacted pond was found to lose $10 \%$ within the first day of filling. On the other hand, the pond treated with a locally available soil-straw mixture was found to have lowest amount of level drop $(5.7 \%)$ than all the other treatments in the same day followed by the termite mound which has $7 \%$.

Therefore, by simply looking in to the first day of water loss from all the ponds, it can be concluded that, the pond treated with the locally available soil-straw mixture is most effective in achieving water tightness followed by the pond treated with termite mound. Moreover, from the study made, it could be seen that the compaction of the pond can relatively help in the attainment of water tightness as compared to the pond that was left untreated. The compacted pond could lose $10 \%$ and whereas the control lost $15 \%$ of water level in the first day. The compacted pond could reserve the ponded water for about two weeks while the control one could only store for a week. By compaction of the ponds, it was possible to store water for 17 days. This amount of water could be lost if the pond was left untreated in 9 days.

To summarize, the pond that retained water for the longest period (about 7 weeks) is the pond treated with a soil-straw mixture. The pond made using termite mound treatment was found to store water for 43 days (about 6 weeks), and compaction alone could increase the storage duration of a pond by a week over the uncompacted, untreated (control) pond. This control pond contained water for only a very short period (only 9 days). In this project area, the dry season is two to three months and the supplemental irrigation of this water harvesting system can help the farmers in the area to safeguard crop failure. 


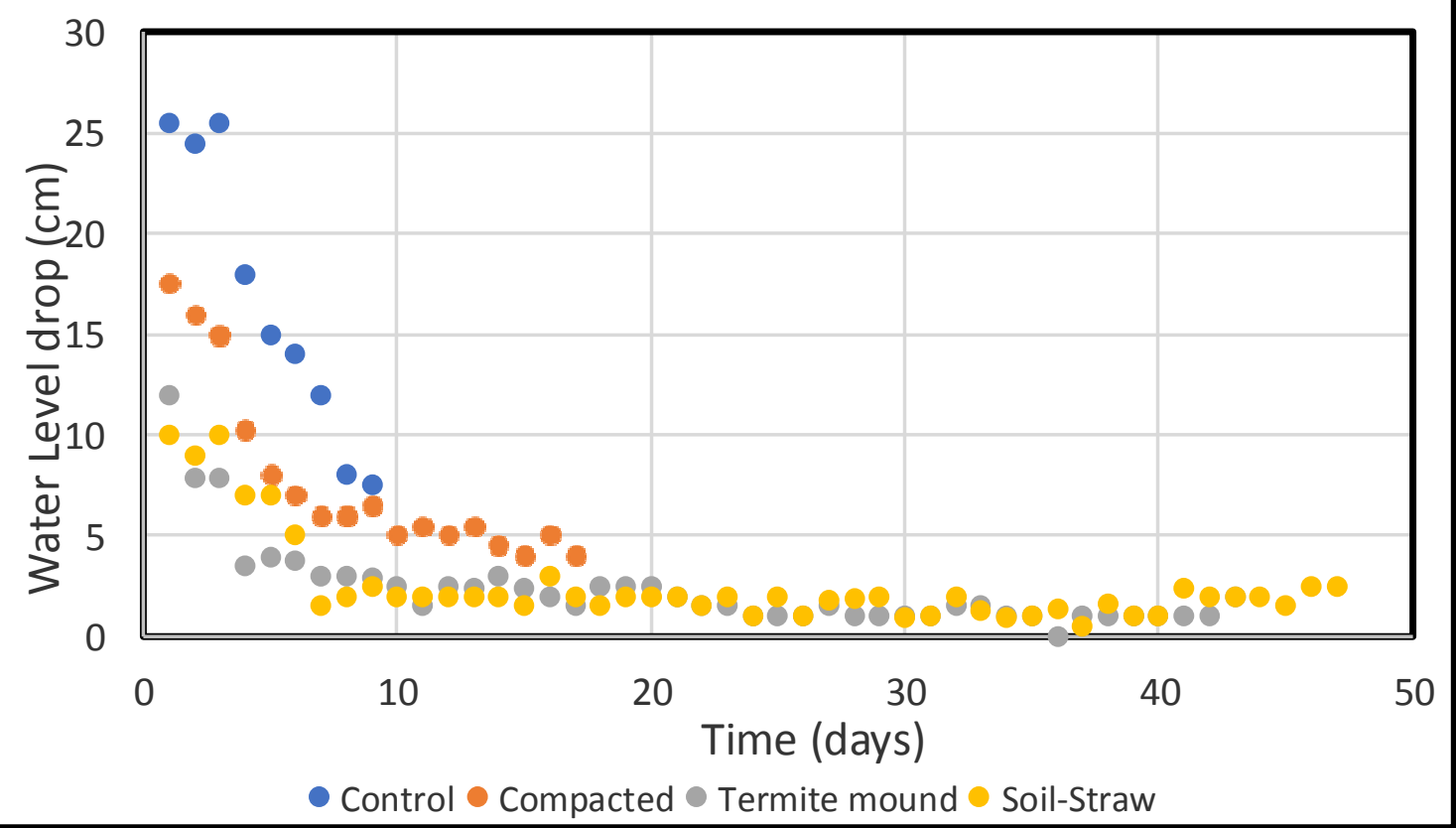

Figure 4.1: Daily water level drop vs time

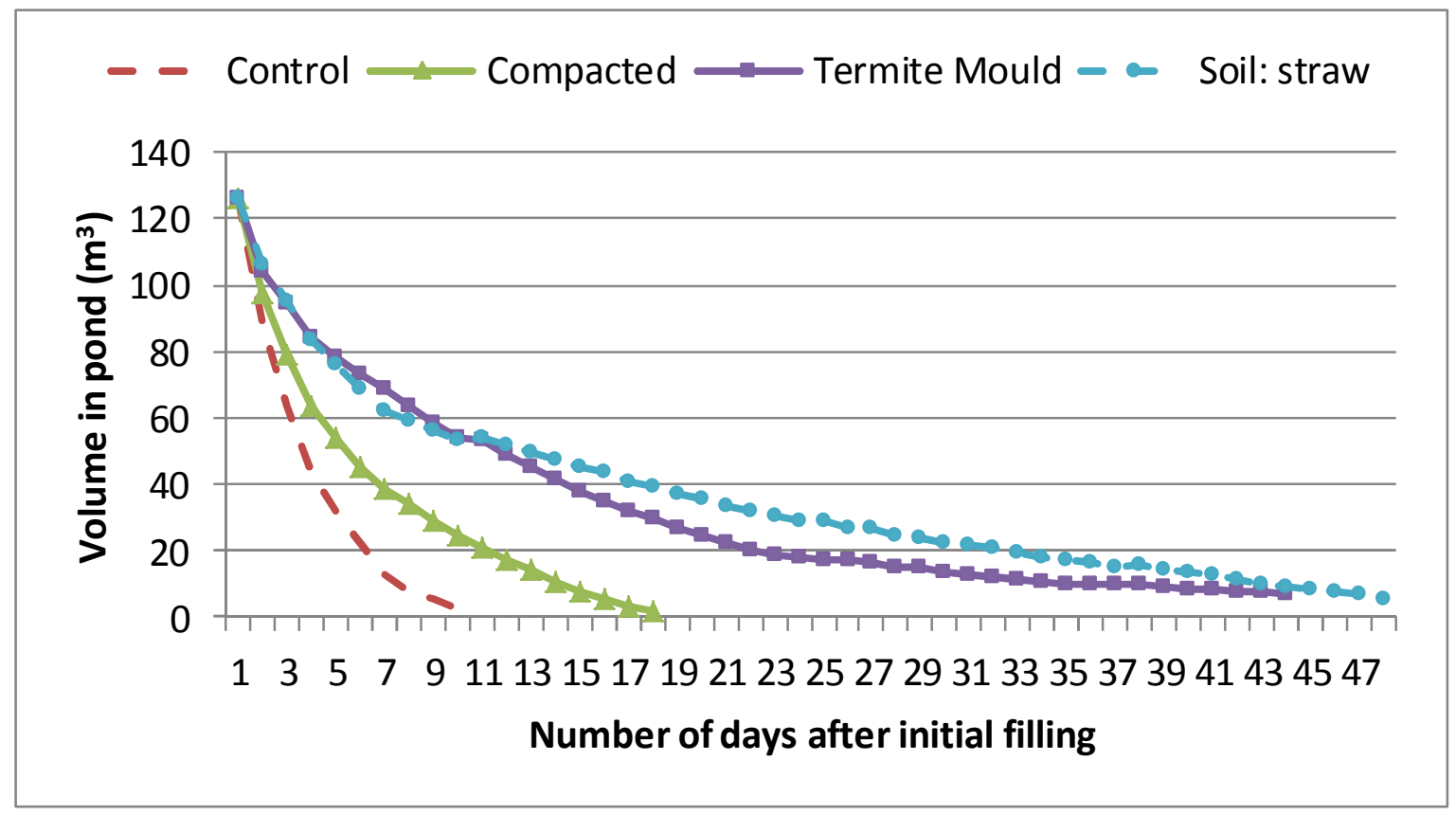

Figure. 4.2 Change in pond volume after filling over 47-day period. (Initial volumes were all at $125 \mathrm{~m}^{3}$ and a depth of $175 \mathrm{~cm}$.) [Note: There was no recorded rainfall during this period.]

\section{Conclusion and Recommendations}

The following conclusions could be drawn from the analysis made above:

a.) Treating the ponds with a soil-straw mixture was found to increase the water tightness in the pond. With only $10 \mathrm{~cm}$ thickness of lining, it was possible to store water for nearly a month and three weeks duration as compared to almost one-week storage amount if left untreated. This option of treatment is also found to be the least cost method as locally available materials were utilized in undertaking the treatments.

b.) Treating the pond with Termite mound (Kuyisa) was also found to increase the water storage time by treating the sides and bottom of the pond to a thickness of $10 \mathrm{~cm}$. It stored water for a month and two weeks. This option is the best for sealing ponds in areas where this treatment material is readily 
available.

b.) Compacting the pond alone is a low-cost improvement could extend the duration of water storage in ponds to about 2.5 weeks; which is an addition of one week than the pond which was left untreated. Therefore, in some areas where the treatment methods proposed to be undertaken are found in applicable, then compaction can be a remedy for some time.

c.) The slope of the untreated pond failed due to erosion while the slope of the treated pond remained stable. Therefore, the different treatment methods used in this study were not only seen to reduce seepage losses from ponds, but also protect slope failure.

d.) The lining thickness of $10 \mathrm{~cm}$ used in this study could reduce seepage losses from ponds to the amount that has been discussed in this study. However, the losses from such ponds could be reduced further by increasing the thickness of lining. It is therefore, necessary to increase the lining thickness and study its effect in further reducing the losses.

Based on the experimental result, the treatment method that resulted in a reduced seepage loss from the pond, the soil-straw mix was found to be the least-cost followed by the termite-mound method.

\section{Recommendations}

In some places in Oromia, e.g. Hararghe, there is a traditional knowledge that ponds contain more water as the age of the pond increases and this is locally termed as "Sidraa' $u$ ". Therefore, the report recommends further study on the aging effect in ponds. It is also recommended to further study the liner thickness. For example, if the soil-straw mixture liner were doubled, it is expected that the time for holding water to be doubled as well. From this study, it was observed that seepage losses can be minimized from ponds by using locally available treatment materials. Therefore, these treatment methods can be employed in place of costly artificial, plastic sealing liners which are often not locally available. The improvement of seepage reduction is a matter of research as indicated above. It is also necessary to strengthen the capacity of the community and institutional structures to provide effective and efficient harvested water management systems.

Recommended future research directions:

- Integrating rainfall and evaporation data into the runoff harvesting systems to better estimate the runoff volume and efficient management of the harvested water.

- Increasing the lining thickness and identifying other lining materials that can potentially reduce seepage losses.

- $\quad$ Promoting/adopting efficient irrigation systems e.g., drip irrigation to minimize the harvested water losses.

\section{Acknowledgment}

This work was funded by the then Ethiopian Science and Technology Commission. We are thankful to Oromia Irrigation Development Authority (OIDA) for facilitating the field works. We are also thankful to Seyoum Getachew for his input on this research work.

\section{References}

Awulachew S. B., Merrey D. J., Kamara A. B., Van Koppen B., Penning de Vries F. and Boelee E. (2005). Experiences and Opportunities for Promoting Small-Scale/Micro Irrigation and Rainwater Harvesting for Food Security in Ethiopia. Working paper 98, Addis Ababa, Ethiopia

Awulachew, S. B., Yilma A. D., Loulseged M., Loiskandl W., Ayana M., Alamirew T. (2007). Water Resources and Irrigation Development in Ethiopia. Colombo, Sri Lanka: International Water Management Institute. 78p. (Working Paper 123)

Beysens D., Milimouk I., Nikolayev V. S., Berkowicz S., Muselli M., Heusinkveld B., and Jacobs A. F. G. (2006). "Comment on The Moisture from the Air as Water Resource in Arid Region: Hopes, Doubt and Facts. by Kogan and Trahtman.” Journal of Arid Environments Vol. 67, pp. 343-352.

Beckers, B., Berking, J., \& Schütt, B. (2013). Ancient water harvesting methods in the drylands of the Mediterranean and Western Asia. eTopoi. Journal for Ancient Studies. vol. 2, pp. 145-164, Berlin.

Bruins, H. J., Evenari M., and Nessler, U. (1986). Rainwater-Harvesting Agriculture for Food Production in Arid Zones: The Challenge of the African Famine. Vol. 6, pp. 13-32.

Cerritelli, W. E., Bantirgu, A., Akalewold, B., Abagodu, R. (2008). Updated Mapping Study on Non-Sector Actors in Ethiopia, Regional report, Vol. II,

Clark, G. A., Stanley, C. D., Zazueta, F. Z., \& Albregts, E. E. (1988). Farm ponds in Florida irrigation systems. Extension Bulletin, 257, 2.

Debsu, D. N. (2013). Local Institutions, External Interventions, and Adaptation to Climate Change: The case of the Borana pastoralists in southern Ethiopia, Oxfam America Research Backgrounder series (2013). [Online] Available: http://www.oxfamamerica.org/publications/climate-change-adaptive- processes-ethiopia. (June 
20, 2009)

Dorota, Z., Haman, Allen G., Smajsterle, Kedro. S., Zaueta and Gary, A. Clark. (June 1990). Selecting a Method for Sealing Ponds in Florida. University of Florida.

Evenari, M., Shanan, L., Tadmor, N., and Aharoni, Y. (1961). Ancient Agriculture in the Negev. Science, New Series 133, pp. 979-996.

FAO (2000). The Elimination of Food Insecurity in the Horn of Africa - Summary Report. Rome: Food and Agriculture Organization. [Online] Available: http://www.fao.org/docrep/003/x8530e/x8530e00.htm (October 11, 2011)

FEWS NET (2011). Ethiopia Food Security Outlook Update, August 25, 2011.[Online] Available: http://www.fews.net/docs/Publications/Ethiopia_Dekadal_08_20_final_ext.pdf(Accessed June 17, 2009).

Fitsum, Hagos., Godswill, Makombe., Regassa, E. Namara and Seleshi, B. A. (2009). Importance of Irrigated Agriculture to the Ethiopian Economy: Capturing the Direct Net Benefits of Irrigation, IWMI Research Report 128

Getachew, A. (1999). Rain water harvesting in Ethiopia: an overview, A report from $25^{\text {th }}$ WEDC conference, Addis Ababa, Ethiopia. [Online] Available: https://wedcknowledge.lboro.ac.uk/resources/conference/25/387.pdf (April 15, 2009).

Gilbertson, D. D. (1986). Runoff (Floodwater) Farming and Rural Water Supply in Arid Lands. Applied Geography. Vol. 6, pp. 5-11.

Giráldez, J. V., Ayuso, J. L., Garcia, A., López, J. G., and Roldán, J. (1988). Water Harvesting Strategies in the Semiarid Climate of Southeastern Spain. Agricultural Water Management, 14, pp. 253-263.

Hagos, F., Makombe, G., Namara, R. E., \& Awulachew, S. B. (2009). Importance of irrigated agriculture to the Ethiopian economy: Capturing the direct net benefits of irrigation (Vol. 128). IWMI.

Hill, J., and Woodland, W. (2003). Contrasting Water Management Techniques in Tunisia: Towards Sustainable Agricultural Use. The Geographical Journal, 169, pp. 342-357.

Hordofa, T., Menkir, M., Awulachew, S. B., \& Erkossa, T. (2008). Irrigation and rain-fed crop production system in Ethiopia.

Thornton, P. K., Jones, P. G., Owiyo, T., Kruska, R. L., Herrero, M. T., Kristjanson, P. M., ... \& Omolo, A. (2006). Mapping climate vulnerability and poverty in Africa.

Stige, L. C., J. Stave K., Chan, L., Ciannelli, N., Pattorelli, M., Glantz, H., Herren, N. Stenseth. (2006). The Effect of Climate Variation on Agro-Pastoral Production in Africa. PNAS, 103: 3049-3053.

JICA, (2013). The project for capacity building in Irrigation Development. [Online] Available: https://www.jica.go.jp/english/our_work/evaluation/tech_and_grant/project/term/africa/c8h0vm000001rp75 -att/ethiopia 2013 02.pdf (May 21, 2019).

Melesse, A., Abtew, W., \& Dessalegne, T. (2009). Evaporation estimation of Rift Valley Lakes: comparison of models. Sensors, $9(12), 9603-9615$.

MoA, (2000). Ministry of Agriculture, Atlas of WBISPP, Oromia Regional State, A.A., Ethiopia.

MoWR, (2001). Initial National Communication of Ethiopia to the United Nations Framework Convention on Climate Change, National Meteorological Services Agency, Ministry of Water Resources, Addis Ababa

MoWR, (2002). Water Resources in Ethiopia, Quarterly Review Magazines, Ministry of Water Resources, Ethiopia

Narpat, S. R. (2011). A Historical Perspective of the Development of Rain Water Harvesting Techniques in the Mewar Region, Udaipur, Rajasthan, India, International Journal of Water Resources and Arid Environments, 1(4): 285-294,

OIDA, (2004). Evaluation Report on Benefits Of water Harvesting Schemes implemented in 1995 E.C, Oromia Irrigation Development Authority.

Prinz, D. (1994). Water Harvesting: Past and Future”. In Sustainability of Irrigated Agriculture. Ed. by L. Pereira. Vol. 312, pp.135-144.

Stokes, L., Scozzaro, A. T., \& Haller, J. (2010). The Food Crisis in Ethiopia \& Egypt: Contrasting Hydrological \& Economic Barriers to Development. Consilience, (3), 117-138.

World Bank, (2005) The World Bank Annual Report 2005, Year in Review 


\section{Supplemental data}

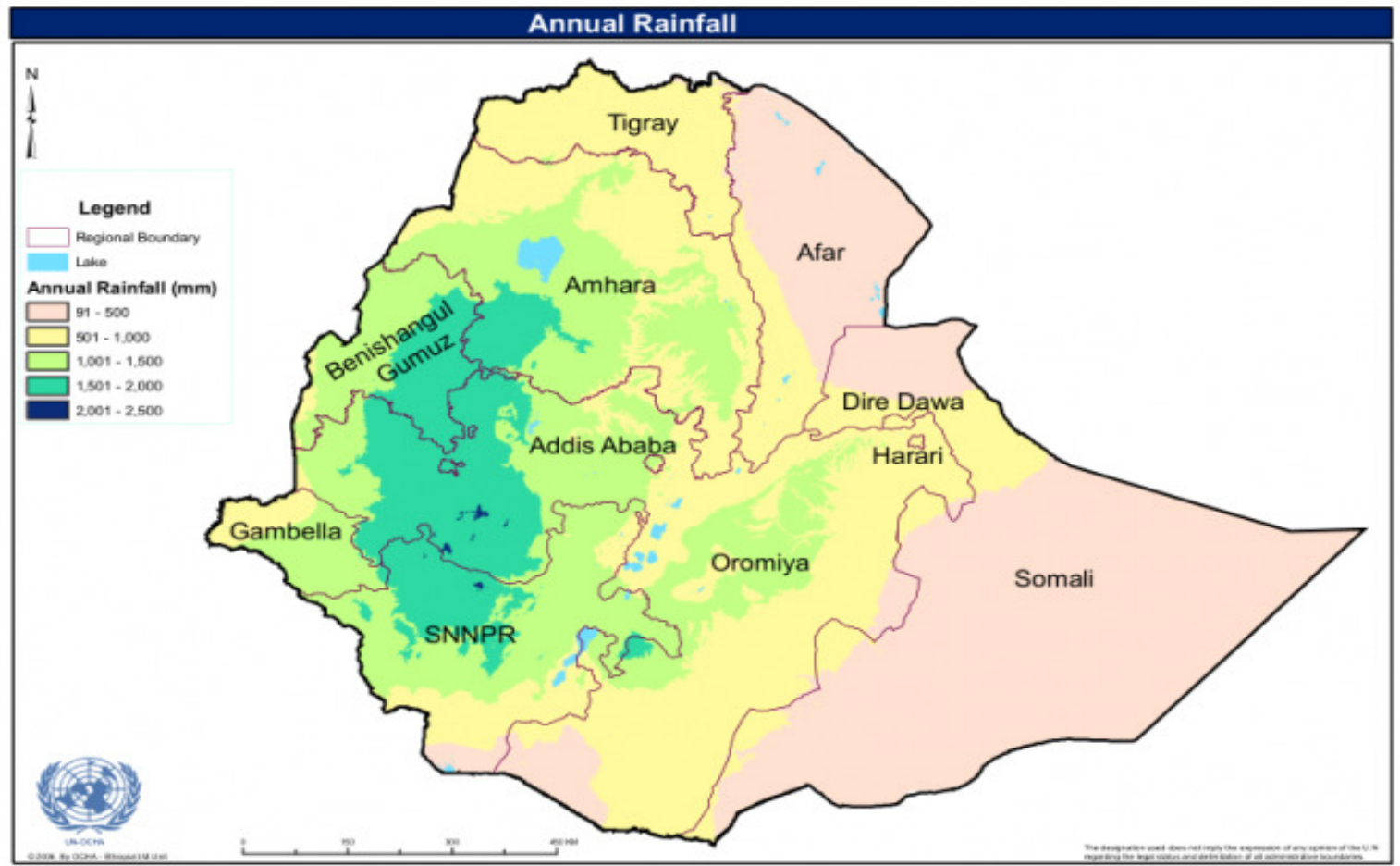

Figure S.1 A rainfall map of Ethiopia. Source: (OCHA 2006)

Historical Pond Data

Table S.1 Pond construction plan and accomplishments in 2004, region of Oromia.

\begin{tabular}{|c|c|c|c|c|c|}
\hline Zone & Plan & Executed & \multicolumn{2}{|c|}{ Contained water } & Area \\
\hline & Nos. & Nos. & Nos. & $\%$ & Developed (Ha) \\
\hline East Hararge & 34700 & 14416 & 5672 & 39.3 & 640.8 \\
\hline West Hararge & 29600 & 20208 & 11797 & 58.4 & 132.7 \\
\hline Bale & 18000 & 7890 & 1087 & 13.8 & 48.3 \\
\hline Borana & 16000 & 5794 & 0 & 0.0 & \\
\hline Gujii & 5860 & 2216 & 480 & 21.7 & 989.5 \\
\hline Arsii & 29450 & 8606 & 2108 & 24.5 & 16.43 \\
\hline E/Shewa & 17450 & 11503 & 7971 & 69.3 & \\
\hline N/Shewa & 31380 & 3510 & 1800 & 51.3 & 36.8 \\
\hline S/W/Shewa & 3520 & 2900 & 797 & 27.5 & \\
\hline W/Shewa & 2380 & 338 & 236 & 69.8 & 22 \\
\hline E/Wollega & 2340 & 111 & 39 & 35.1 & 1.91 \\
\hline W/Wollega & 1500 & 312 & 0 & 0.0 & \\
\hline I/A/Bora & 1840 & 171 & 0 & 0.0 & \\
\hline Jimma & 2050 & 868 & 0 & 0.0 & \\
\hline Total & 196070 & 78843 & 31987 & 40.6 & 1888.4 \\
\hline
\end{tabular}

Source: Oromia Bureau of Agricultural Resource Development (OBARD), Water harvesting Team 
Table S.2. List of constructed ponds and their status in East and West Harargehe zones, Oromia, January 2004 January 2005.

\begin{tabular}{|c|c|c|c|c|c|c|c|}
\hline & Name of District & $\begin{array}{l}\text { Constructed } \\
\text { Ponds (Nos.) }\end{array}$ & $\begin{array}{l}\text { Contained } \\
\text { water (Nos.) }\end{array}$ & $\begin{array}{l}\text { Utilized } \\
\text { Ponds } \\
\text { (Nos) }\end{array}$ & $\begin{array}{l}\text { Irrigated } \\
\text { Area (Ha) }\end{array}$ & $\begin{array}{l}\text { Yield } \\
\text { obtained } \\
\text { (Qt) }\end{array}$ & $\begin{array}{l}\text { Benefit } \\
\text { Obtained } \\
\text { (Birr) }\end{array}$ \\
\hline \multirow{17}{*}{ 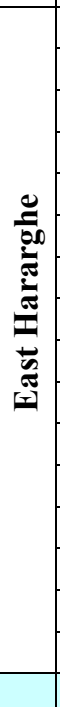 } & Babile & 1218 & 457 & 399 & 11.97 & 128 & 126000 \\
\hline & Badano & 744 & 119 & 119 & 3.63 & 170 & 31100 \\
\hline & Dadar & 1705 & 952 & 952 & 18.5 & 725 & 90000 \\
\hline & Fadis & 1738 & 236 & 16 & 0.16 & 4.6 & 630 \\
\hline & Giraawaa & 756 & 155 & 155 & 5.66 & 85 & 19375 \\
\hline & Gola Oda & 1251 & 505 & 505 & 8.67 & 50 & 5000 \\
\hline & Goro Gutu & 1708 & 305 & 305 & 9.15 & 911 & 223055 \\
\hline & Gursum & 271 & 232 & 232 & 56 & 615 & 107305 \\
\hline & Haromaya & 512 & 380 & 380 & 15.2 & 1008 & 60480 \\
\hline & Jarso & 302 & 150 & 150 & 4.5 & 320 & 5280 \\
\hline & Kombolcha & 501 & 113 & 0 & 0 & 0 & 0 \\
\hline & Kurfa Callee & 147 & 72 & 72 & 84.13 & 64.55 & 17569 \\
\hline & Malka Balo & 1381 & 444 & 420 & 8 & 590 & 10200 \\
\hline & Mayu Muluqee & 716 & 209 & 47 & 3.8 & 46 & 5520 \\
\hline & Meeta & 1200 & 495 & 186 & 5.58 & 408 & 9000 \\
\hline & Qarsa & 776 & 248 & 248 & 23 & 917 & 54510 \\
\hline & Total & 14926 & 5072 & 4186 & 257.95 & 6042.15 & 765024 \\
\hline \multirow{11}{*}{ 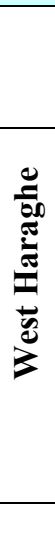 } & Name of District & $\begin{array}{l}\text { Constructed } \\
(\text { Nos })\end{array}$ & $\begin{array}{l}\text { Contained } \\
\text { water (Nos.) }\end{array}$ & $\begin{array}{l}\text { Utilized } \\
\text { Ponds } \\
\text { (Nos) }\end{array}$ & $\begin{array}{l}\text { Irrigated } \\
\text { Area (Ha) }\end{array}$ & $\begin{array}{l}\text { Yield } \\
\text { obtained } \\
(\mathrm{Qt})\end{array}$ & $\begin{array}{l}\text { Benefit } \\
\text { Obtained } \\
\text { (Birr) }\end{array}$ \\
\hline & Ancar & 914 & 30 & 17 & 7.75 & 881.3 & 51610 \\
\hline & Boke & 1423 & 416 & 416 & 12.5 & 405 & 49905 \\
\hline & Ciro & 5421 & 3521 & 1990 & 59.7 & 2902 & 1684 \\
\hline & $\mathrm{D} / \mathrm{Labu}$ & 3550 & 2130 & 1394 & 19.44 & 290 & 23747 \\
\hline & Daba & 903 & 903 & 810 & 15.8 & 3371 & 405340 \\
\hline & Habro & 2351 & 721 & 54 & 54 & 1454 & 259970 \\
\hline & Kuni & 1387 & 252 & 70 & 7.06 & 518 & 37019 \\
\hline & Mesela & 2570 & 2528 & 2521 & 124.85 & 6086 & 856102 \\
\hline & Tulo & 1010 & 742 & 381 & 10.15 & 642 & 91807 \\
\hline & Total & 19529 & 11243 & 7653 & 311.25 & 16549.3 & 1777184 \\
\hline
\end{tabular}

Source: Oromia Bureau of Agricultural Resource Development OBARD); Irrigation Water Management and Soil Conservation Department 